\title{
Furthering the conditions for the accumulation of capital
}

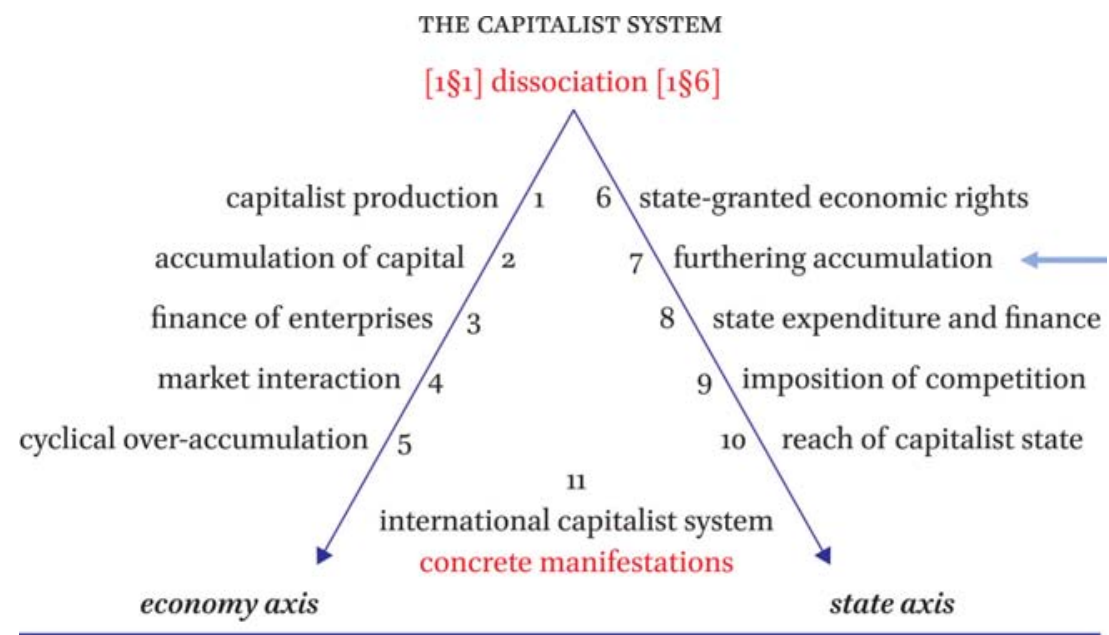

\section{Contents}

Introduction 333

Division 1. The state's action radius predicated on its furthering the conditions for capital accumulation 335

$7 \S 1$ The material existence of the state: taxation and the state's action radius 335

$7 \S 2$ The fundamental conflict of taxation 335

$7 \S 3$ The tax base, the potential action radius of the state, and the state's furthering of the conditions for the accumulation of capital 336

Division 2. The monetary framework 340

$7 \S 4$ Imposition of the monetary standard of the Central Bank 340

$7 \S 5 \quad$ Money and its grounding in monetary legislation 341

$7 \S 6 \quad$ Conflicts of monetary regulation $\quad 342$

$7 \S 7$ Delegation of the specific regulation, of the supervision of its execution and of monetary policy to the central bank: purification from conflict 342

(C) GEERT REUTEN, 2019 | DOI:10.1163/9789004392809_010

This is an open access chapter distributed under the terms of the prevailing CC-BY-NC-ND License at the time of publication. 
$7 \S 8 \quad$ The objective of reaching creeping inflation $\quad 344$

$7 \S 9 \quad$ Banking crises and the movement to 'too big to fail'-banks 344

Division 3. The labour-capacity framework 346

$7 \S 10$ Minimum wage: the reproduction of the current labour population 346

$7 \S 11$ Delegation to minimum wage commissions or councils 348

$7 \S 12$ Temporary unemployment benefits 348

$7 \S 13$ Labour population growth 349

$7 \S 14$ Public education 351

Division 4. The infrastructural framework 355

$7 \S 15$ Infrastructure 355

$7 \S 16 \quad$ Fundamental technology research 357

Division 5 . The social security framework $35^{8}$

$7 \S 17$ Legitimation: compliance-dependent social security transfers 359

Division 6. Separation of the state's administrative and judiciary branches 365

$7 \S 18$ Arbitration and sanctioning - legitimising assignment to a separated off

Judiciary, as a separation-in-unity with the main body of the state 365

Division 7. Separation of the state's administrative and deliberative branches $\quad 367$

$7 \S 19$ Taxation and the overriding of property right 368

$7 \S 20$ Conflicts of the form of taxation 368

$7 \S 21$ The worrying or reassuring state's share in the economy 369

$7 \S 22$ General conflicts of right and of legitimation in compliance 370

$7 \S 23$ Conflict modification - legitimising assignment to a separated off

Deliberative, as a separation-in-unity with the main body of the state 371

Summary and conclusions $\quad 375$

Appendix 7 A. Data and data sources of the graphs in chapter $7 \quad 377$

List of figures chapter $7 \quad 382$ 


\section{Introduction}

The exposition in Chapter 6 showed that the capitalist economy cannot exist by itself and that its reproduction necessarily requires the state to grant core economic entitlement claims in the form of legal rights. This chapter starts by setting out that the material grounding of the state and its actions requires it to collect means from the economy in the form of taxation. Hence taxation overrides property right. Thus we have the paradox that the state's upholding of property right must intrude property right.

The 'action radius of the state' is that which it can do given the constraint of feasible taxation. The latter is determined by the prevailing condition of the accumulation of capital. The capitalist state's necessary action in face of feasible taxation determines (the degree of) its furthering the conditions for the accumulation of capital. The main body of this chapter consists of the exposition of these conditions. First, monetary conditions (Division 2). Secondly, conditions regarding the quantity and quality of the supply of labour-capacity (Division 3). Thirdly, conditions regarding the economy's infrastructure (Division 4). Especially the concretisation of the second and third conditions require extra state expenditure and hence taxation. However, the feasibility of taxation concerns not so much its absolute amount, but rather the feasibility of tax rates.

A (potentially) quantitatively important category of state expenditure concerns social security provisions. These, and their requirement in face of the legitimation of the state, are presented in Division 5 .

Whereas action of the state on all these terrains is necessary, we will see throughout this chapter that the degree is the crucial point. This opens up continuous sources of conflict, which may threaten the legitimation of the state. The last two divisions show how potential conflicts in respect of this legitimation require two major separations within the body of the state. As a result the state exists institutionally within three bodies. The core one is the Administrative, with next to it the bodies of the Judiciary (Division 6) and the Deliberative (Division 7). The latter's seeking of compliance, and ultimately its actual generation of compliance, is an indispensable condition for the existence of the state, and hence for the capitalist system.

Throughout this chapter I never use the term 'state intervention'. I consider that term to be highly ideological to the extent that it is based on the presumption that the capitalist economy could possibly stand on itself. Instead, the capitalist economy and state constitute a necessary unity, be it institutionally distinct as a 'separation-in-unity'.

The current chapter presents the first conditions of existence of the exposition in Chapter 6. At the same time it is the sequel to the exposition in 
SCHEME 7.1 The conditions furthering the accumulation of capital (outline Chapter 7)

The capitalist state in general

[Chapter 6]

$\downarrow$

Furthering of the conditions for capital accumulation

$\left[{ }_{7} \mathrm{D}_{1}\right]$

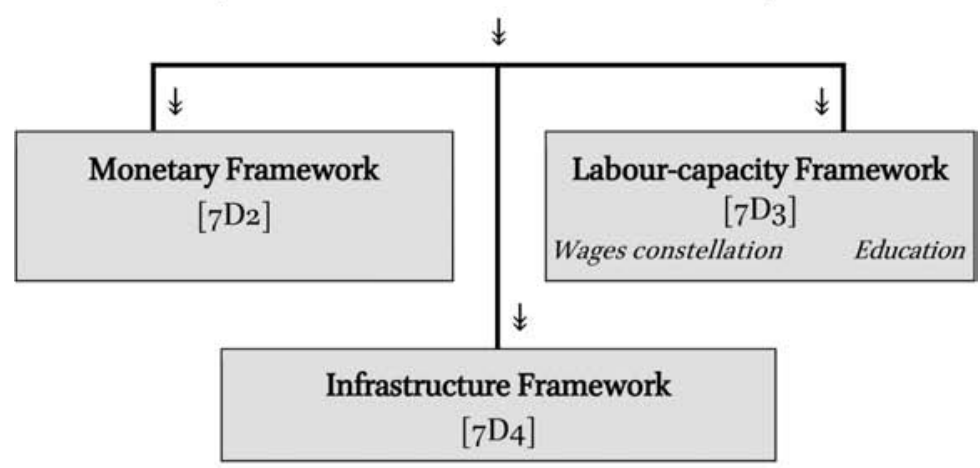

Continuous legitimation requirement (implied by 6D3)

grounding all previous moments

$\downarrow$

indeterminate degree of social security provisions

Social security Framework

$\left[{ }_{7} \mathrm{D}_{5}\right]$

\section{Modification of continuously reappearing conflicts of} regulation implied by all previous moments

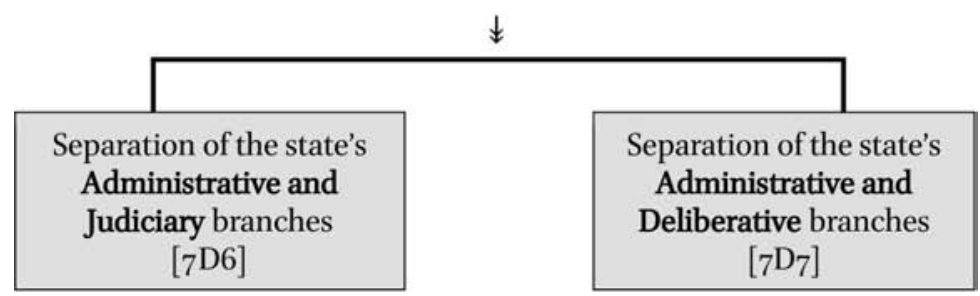

Legend

$\downarrow$ grounded in (conditioned by) 
Chapter 2, setting out the latter's conditions of existence, especially regarding the accumulation of capital and its moments of the expansion of money and of labour-capacity (Divisions 2 and 3 of the current chapter).

The main moments presented in this chapter are summarised in Scheme 7.1.

\section{Division 1. The state's action radius as predicated on its furthering of the conditions for the accumulation of capital}

General terminological note: I use the term regulation for the entirety of laws and of the 'delegated regulation'. When I explicitly refer to the latter I always use the adjective 'delegated'. When I refer to 'regulation', this refers, as said, to the entirety. (See further 10§2.)

\section{$7 \S 1 \quad$ The material existence of the state: taxation and the state's action radius}

The state's action of the legislation and upholding of right (6D4-6D6) necessarily requires its material reproduction. For that material reproduction the state is dependent upon the economy. The form of separation (6§6) requires, at least in principle, that the state itself does not engage in profit-generating processes of production out of which it might finance its action. Therefore the state is compelled to appropriate means from the economy by taxation. Thus taxation grounds the action radius of the state.

$7 \S 1-\mathrm{a} \quad$ Explication. The state and profit-generating processes

The main text refers to an abstaining 'in principle'. In fact, for the average of the OECD-21 countries in the early twenty-first century, about $2 \%$ of the total labour force is employed in state enterprises. To be sure: the proceeds from it far from cover the total state expenditure (around the same time on average about $45 \%$ of GDP).

\section{$7 \S 2 \quad$ The fundamental conflict of taxation; the tax base and the tax rate}

The state's material reproduction via taxation $(7 \S 1)$ implies that its maintenance of right requires the overriding of property right through taxation. Hence taxation is fundamentally conflicting. This fundamental conflict cannot be overcome, even if it can be moderated. (I systematically bracket this fundamental conflict until the last division of this chapter $-{ }_{7} \mathrm{D}_{7}$.)

Quite apart from the fundamental character of this conflict, the degree of conflict is determined by the tax base or the tax bases (that on which taxes are levied) and the rate of taxation. The tax base is the value amount of the income 
or property that can in principle be taxed. Thus if the state requires an amount of $x$ in taxes, the macroeconomic tax base (for example, the amount of surplusvalue) determines the tax rate $(\mathrm{t} \%)$ that generates $\mathrm{x}$.

7§2-a Explication. Taxation in general

The previous sections - and all of this chapter - posit taxation in general. Chapter 8 presents the various forms of taxation (such as particularly on property, income or expenditures) as well as their effect on profits in face of the accumulation of capital.

\section{$7 \S 3 \quad$ The potential action radius of the state, the tax base and the state's furthering of the conditions for the accumulation of capital}

The 'action radius of the state' is that which it can do given the constraint of feasible taxation. So far, this action radius is demarcated merely by what was presented in Chapter 6. Thus the state's action radius is grounded in feasible taxation $(7 \S 1)$, which is determined by the 'tax base' and a concomitant 'tax rate' (7\$2). The tax base (e.g. that of surplus-value) is again grounded in a constellation of the accumulation of capital (Chapter 2). Thus a prevailing constellation of accumulation would constrain the action radius of the state one that may not be sufficient for its necessary action. Given the constraint of feasible taxation, the capitalist state's necessary action requires it to further the conditions for the accumulation of capital. Hence the latter is inherent to the constellation of the capitalist state (methodologically this characteristic again grounds the state's existence - summarised in Scheme 7.2).

Whereas this furthering is qualitatively an important determination of the state, the continuously crucial point is its quantitative degree in face of feasible tax rates.

Thus the state must seek to further the conditions for the accumulation of capital and along with it the conditions for economic growth. ${ }^{1}$ Hence these conditions are instrumental for taxation, the maintenance of the legal rights that the state grants, and the legitimation of the state. Nevertheless economic growth, together with accumulation of capital, tends to be defended in terms of

1 Recall from $2 \S 3$ that 'accumulation of capital' or 'economic growth' is a matter of perspective. The state can alternate between these perspectives. The perspective of the accumulation of capital will be popular in discourses between the state and enterprises; the perspective of economic growth can be more appropriate for the formulation of policy in terms of 'the general interest', not excluding though that accumulation of capital is appropriately phrased in terms of 'the general interest'. (This is also a matter of the contingent ideological climate.) 
the 'general interest. ${ }^{2}$ This way the state at least presents this as an independent objective even if the tax base might be its primary concern. It does not really matter in what order the state itself presents this in actual practice. Whatever the order, the state must seek legitimation in the compliance of actors not only

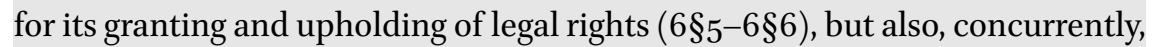
for its furthering the conditions for economic growth.

As a consequence the monetary-value dimension $\left(1 \mathrm{D}_{2}\right)$ is a constitutive element of the considerations of the state. This applies inherently for taxation and economic growth. Regarding legal rights we have as effect that their specific concretisation in legislation is formulated not only within a qualitative legal discourse, but also - especially in the 'explanatory memorandums' of legislation - in terms of costs and benefits, that is, in terms of the discourse of the quantitative monetary-value dimension.

The next divisions present the three main levers for the state's maintenance and improvement of the conditions for economic growth, that is, those regarding money and banking $\left({ }_{7} \mathrm{D}_{2}\right)$, labour-capacity $\left({ }_{7} \mathrm{D}_{3}\right)$, and the economic infrastructure $\left({ }_{7} \mathrm{D}_{4}\right)$.

SCHEME 7.2 The grounding of the state's action radius in its furthering of the conditions for the accumulation of capital (systematic of $7 D_{1}$ )

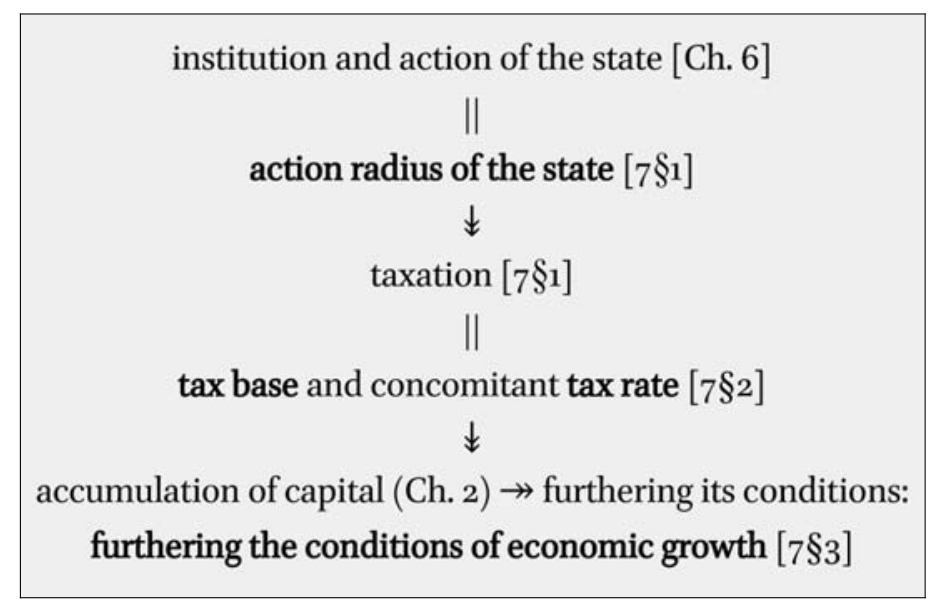

Legend

$\star$ grounded in

\| implicit in the previous moment

2 Recall from $6 \S 6$ that 'the general interest' is inevitably 'the putative general interest': the state 
7§3-a Explication. Simplification by assuming surplus-value to be the unique tax base

The main text of $7 \S 3$ provides the conceptual grounding for what the state does in actual practice: economic policy; as well as for what it frames as one of the main objectives of economic policy: the stimulation of economic growth. That section also provides the grounds of what mainstream economic theory casually calls the reparation of (potential) 'market failures' - set out in Divisions $2-4$.

The main text is perhaps more transparent when, as a provisional simplification, it is assumed that all taxes are levied on surplus-value - prior to any distribution of surplus-value. (In Chapter 8, other taxes, in part substituting for this tax, will be introduced.) This implies that surplus-value is the unique tax base. The tax base constrains the action radius of the state - so far, that which is presented in Chapter 6. In the hypothetical case of zero surplus-value, the action radius would be zero (this would entail an impossibility theorem, to the extent that capitalism cannot exist without the state). This implies that the state for its action radius, and possible extensions of it, must be concerned with the tax base and its growth. More generally, therefore, the state must seek to further the conditions for the accumulation of capital and along with it the conditions for economic growth. Note that given a certain action radius, an increasing tax base - for now increasing surplus-value - may alleviate the tax rate and hence the degree of conflict referred to in $7 \S 2$ (and the other way around for a decreasing tax base).

$7 \S 3^{-b} \quad$ Amplification. A very rough proxy for the long-run development of the tax base

Graph 7.3 shows the average real-GDP per capita growth rate for up to 21 current OECD countries from 1870-2010 (arithmetic average; see Appendix 6A on the OECD-21 and arithmetic averages). This should serve as a very rough proxy for the development of the average tax base. For that purpose, and for this group of countries, during especially the nineteenth-century period, only these data are available. We will see later on (8D2) that until about 1913 state tax receipts were quite below $10 \%$ of GDP for the average of the same group of countries; then after a considerable rise between 1913 and 1920, taxes rose continuously after 1937. The top panel of Graph 7.3 (growth rate per year) shows that prior to 1945 the GDP per capita growth rate developed more erratically than there-

proposes its actions to be in what the state itself considers to be the general interest. Other actors may have different views about what the general interest would be. 
after. The bottom graph shows decade averages. The bold suggestion is that the state's furthering of the conditions of economic growth emerged gradually flattening off after about 1980. This is empirically substantiated for the OECD21 in Amplifications of the rest of this chapter.

It should be emphasised that because business cycles are not synchronous between countries, Graph 7.3 does not picture the business cycle, as this averages picture has severely flattened these. (I return to the business cycle in Chapter 10.)

\section{GRAPH 7.3 Real-GDP per capita 1870-2010, growth rate per year (top} graph) and average per decade (bottom graph); average of 20-21 current OECD countries in 2011 US\$
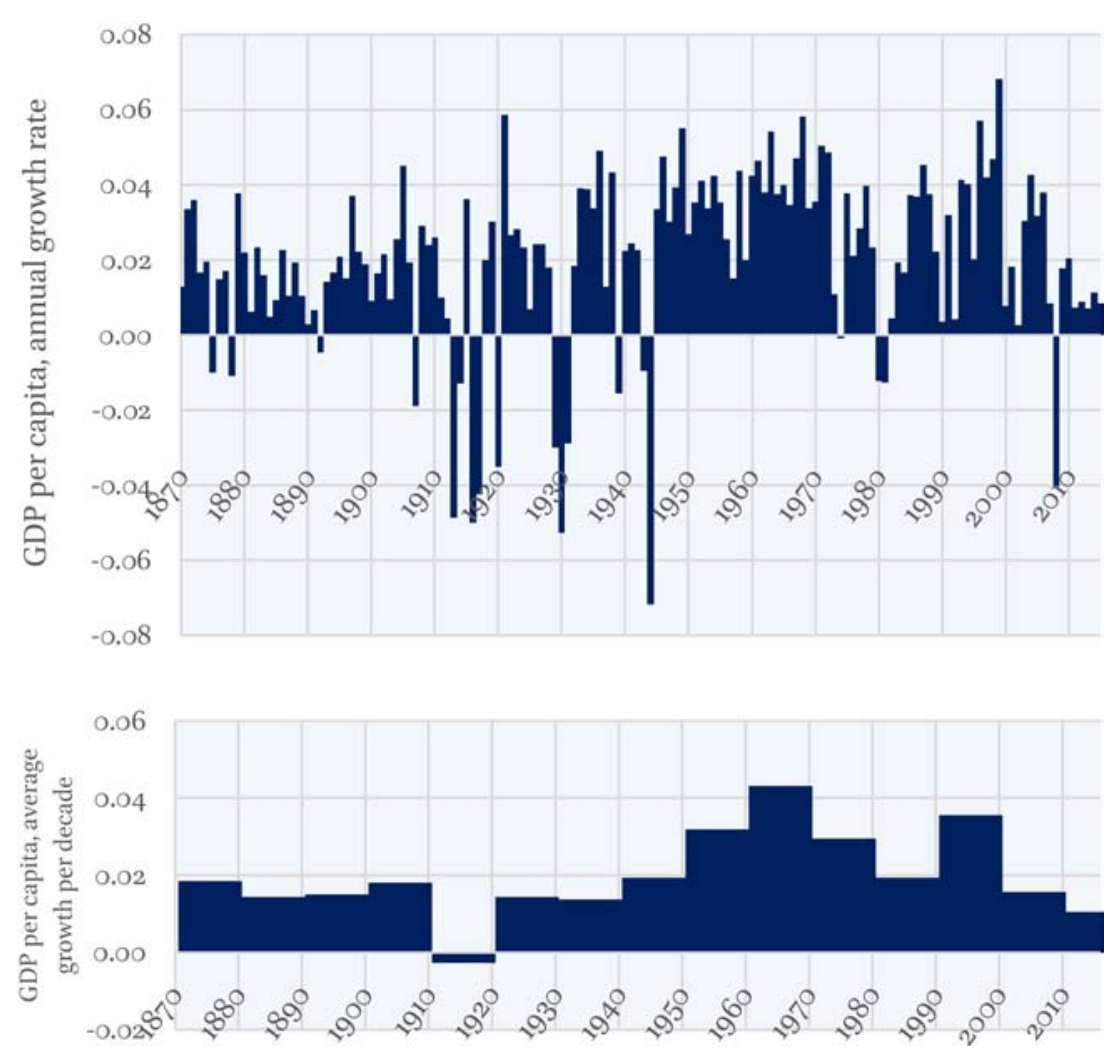

DATA SourCE: Maddison Project Database, version 2018 by Jutta Bolt, Robert Inklaar, Herman de Jong and Jan Luiten van Zanden. See Appendix $7 \mathrm{~A}$, under $7 \S 3$-b, for more information on the data 


\section{Division 2. The monetary framework}

From taxation to monetary regulation furthering accumulation of capital

This division presents the first of the three main levers for the state's furthering of the conditions for economic growth (next to ${ }_{7} \mathrm{D}_{3}$ and ${ }_{7} \mathrm{D}_{4}$ ). The current division is also the sequel to $2 \mathrm{D}_{4}$ on the expansion of money as grounding the accumulation of capital.

\section{$7 \S 4 \quad$ Imposition of the monetary standard of the Central Bank}

The material existence of the state requires it to appropriate means from the economy $(7 \S 1)$. It is in keeping with the monetary-value dimension of the capitalist economy that the state enacts taxation of economic actors in monetary form, rather than in the form of specific useful objects or services.

Recall from Chapter 2 that the extent of the domain of operation of the money created by banks is an important determinant for the collaboration of banks under the umbrella of a dominant bank which adopts the role of Clearing Bank, grounded in monetary rules set by that Clearing Bank $(2 \S 9)$. Recall also that there may be several such Clearing Banks.

This collaboration between banks, or rather the extension of the collaboration, is reinforced by the state. The state will likely have relations with a dominant bank (i.e. a Clearing Bank). On the one hand, the state will require that taxation be paid in terms of the monetary standard of its Clearing Bank. On the other hand, the state will require that its payments be unconditionally accepted by economic subjects. Hence the state imposes payment in terms of the monetary standard of 'its' Clearing Bank. Herewith all banks are required to adopt the monetary standard of the state's Clearing Bank, now the Central Bank.

All the determinants concerning the Clearing Bank and its connection to commercial banks as presented in $2 \mathrm{D}_{4}$, apply to the Central Bank. Because the state is a client of the Central Bank, the latter may provide money-creating loans to the state (similar to the Clearing Bank providing such loans to its clients). The Central Bank tends to abstain from competition with common banks regarding all actors apart from the state (in which case the state is its only nonbank client).

$7 \S 4$-a Amplification. Legal tender

In $7 \S 4$ I have avoided using the term 'legal tender'. This term may refer to the type of payment that is protected by law, which is what $7 \S 4$ refers to. However, even in the second decade of the twenty-first century, the term often also refers to a type of money itself, especially notes issued by the Central Bank. This is 
confusing, because the US Treasury, for example, does not expect actors to pay taxes in dollar notes (not even 'ultimately').

$7 \S 4$-b Explication. No monopoly of money creation for the Central Bank The last sentence of $7 \S 4$ re-establishes that the current exposition is at the same level as that of Chapter 2. In 2D4 when the Clearing Bank was 'merely' presented as the bankers' bank, capitalist money $\left(\mathrm{1D}_{2}\right)$ was concretised as bankcreated money. Now $(7 \S 4)$ this is 'stamped' by the state as legally enforced capitalist money.

Regarding money creation the current division introduces nothing new, other than that one Clearing Bank is now stamped as Central Bank. This merely implies that its monetary standard (a standard such as 'dollar') acquires a monopoly status. It does not imply that the Central Bank has the monopoly of creating money, even if it may have the monopoly of issuing its banknotes (i.e. its own bank notes). On the contrary, ordinary banks do the vast majority of the money creation, and they may also issue their own 'notes', for example, in the form of cheques. (In non-crisis times, ordinary banks do virtually all of the money creation.)

\section{$7 \S 5 \quad$ Money and its grounding in monetary legislation}

The state's imposition of the monetary standard of 'its' bank $(7 \S 4)$ implies that it takes responsibility for the actions of the Central Bank (CB).

This, primarily, determines the concrete grounding of money in monetary legislation. It is necessary because the state (Chapter 6), and hence taxation in monetary form, is necessary to the existence of the capitalist economy.

Secondly, monetary legislation is further determined by the state's requirement of furthering the conditions for economic growth, and hence the accumulation of capital ( $7 \S 3)$.

Monetary legislation includes: first, rules regarding the status of the $\mathrm{CB}$; second, rules regarding the authorisation for financial enterprises to operate as bank; third, a general framework for the rights and duties of banks regarding their client debtors and creditors; fourth, a general framework for the supervision of banks. (See the next three sections.)

7§5-a Explication. Supervision and banking licence

Regulation regarding the authorisation, or licence, for financial enterprises to operate as bank, as well as the general framework for the supervision of banks $(7 \S 5)$, may not be very different from the concern of the Clearing Bank (ClB) regarding a standard for securities and liability rules $(2 \S 9 ; 2 \S 9$-b). (Recall that these may include conditions on the banks' degree of solvency, on various 
reserve ratios, on maturity matches, on the interest rates (margins) charged, as well as enforced loans of banks with the ClB.) The main difference now $(7 \S 5)$ is that the ordinary banks that do not comply can be fined or may ultimately lose their banking licence.

\section{$7 \S 6 \quad$ Conflicts of monetary regulation}

Although monetary legislation is necessary $(7 \S 5)$, the degree of its detail is contingent. This degree of detail determines the executive room for manoeuvre for, on the one hand, the state itself and, on the other, the CB.

This possible room for manoeuvre regards, for example, the placement of state loans or bonds with the CB. Monetary legislation might also be (non-)specific about the monetary accommodation of the development of the general price level (cf. $4 \mathrm{D}_{3}$ ) and of monetary stabilisation regarding the business cycle (cf. 5D2). Such (non-)legislation includes the level of the rate of interest (either as a target or as a (semi-)instrument).

This room for manoeuvre also regards the tightness of standards for securities and liability rules (generally the composition of the banks' balance sheet $2 \S 9-\mathrm{b}$ ), as well as the intensity of the supervision of banks. The degree of tightness poses the main dilemma of the state's monetary policy: tight prudential regulation affects the banks' accommodation of economic growth negatively; loose regulation increases the risk of bank crises.

In any case - be it via legislation or via executive room for manoeuvre - the state necessarily has to make legislative and/or executive choices (in the latter case, the priority, interpretation, and specification of regulation). These choices affect the distribution of income directly (prices, interest) as well as, indirectly, investment and unemployment. This implies that the state has to take a side in the (potential) conflicts between labour, enterprises and financiers. Hence - as with restrictions on the production process in face of labour protection $(6 \S 16)-$ the state's reference to the 'general interest' (6§6) and its self-imposed (putative) impartiality (6\$7) may erode, so distorting the ground for its legitimation $(6 \S 5)$.

\section{$7 \S 7 \quad$ Delegation of the specific regulation, of the supervision of its execution, and of monetary policy to the Central Bank: purification from conflict}

For its monetary regulation the state has to make regulative choices that may distort its legitimation $(7 \S 6)$. Therefore the state tends to enact a general framework for the objectives and tasks of the Central Bank as including its supervision of the other banks. Next it tends to delegate the specific regulation, the execution of its supervision as well as monetary policy to the putatively 
(semi-)independent Central Bank (see $7 \S 7-a)$. Through this delegation (and analogous to the earlier delegation - 6§16), the state purifies its core administrative body from conflict (to some extent). Nevertheless the state is ultimately responsible for the actions that it delegates. ${ }^{3}$ However, in case of disasters or heavy conflict, the state can dismiss and replace the board of the CB, so evading heavy effect on its own legitimation. ${ }^{4}$

Scheme 7.4 summarises the sequence of the grounding moments presented so far in the current division.

\section{SCHEME 7.4 From taxation to conflicts of monetary regulation} and conflict delegation (systematic of $7 D_{2}, 7 \$_{4-}$ $7 \S 7)$

Taxation

\begin{tabular}{|c|}
\hline$(7 \mathrm{D} 1)$ \\
\hline $\begin{array}{c} \\
\text { Imposition of the monetary standard of } \\
\text { 'the' Central Bank } \\
(7 \S 4) \\
\downarrow \\
\text { Monetary legislation } \\
(7 \S 5) \\
\| \\
\text { conflicts of execution monetary regulation } \\
\text { (executive choices; take a side in the conflicts between } \\
\text { labour, enterprises and financiers) } \\
(7 \S 6) \\
\ddagger \\
\text { conflict dealing delegated to the Central Bank } \\
(7 \S 7)\end{array}$ \\
\hline
\end{tabular}

3 Both the delegation and the ultimate responsibility of the state are revealed in the following citation. In 2013 the Minister of Finance of the Netherlands, Dijsselbloem, stated to the country's Senate: '... The Netherlands decided to actualise its monetary policy by delegating it to the European level. The state ultimately determines the "monetary constellation". In the theoretical case in which the euro area would cease to exist, the Netherlands would have to decide again in what way it would want to reshape its monetary policy.' ['Zoals uit bovenstaande blijkt heeft Nederland ervoor gekozen om haar monetaire beleid vorm te geven door deze te delegeren naar het Europese niveau. De Staat is dus uiteindelijk bepalend voor de "monetaire constellatie". In het theoretische geval dat het eurogebied zou ophouden te bestaan ontstaat er voor Nederland een nieuwe situatie en zal zij opnieuw moeten kiezen op welke manier zij het monetaire beleid vorm zal willen geven:'] (Ministry of Finance of the Netherlands 2013, p. 15).

4 It might make this more difficult when the appointment term is fixed for a number of years, without constraints. 
7§7-a Explication. The delegation to the 'technocratic' CB and the inevitable ultimate responsibility of the state.

The delegation of tasks to the CB does not mean that CB policies are cast 'more' in 'the' general interest than in the absence of such delegation. Delegation is merely a means to protect the main body of the state from conflict. This goes against the mainstream assumption that a Central Bank is more independent than (the rest of) the state. This presumes, by the way, that the state is not independent (vis-à-vis the capitalist economy, the state is indeed a capitalist state, but I doubt that this is the quarrel). Thus, those who are sometimes called CB 'technocrats' have to formulate the content of their view on the (monetary) general interest. However, these technocrats are no more disconnected from interests (particularly those of banks - perhaps large banks) than other actors. Yes, they like to be labelled as 'independent'.

Because the state in fact delegates the conflict dealing to the CB (regarding especially the distribution of income and wealth $-7 \S 6$ ), it is not only in the interest of the $\mathrm{CB}$ but foremost in the interest of the state to 'advertise' the $\mathrm{CB}$ as being an 'independent' institution.

However, this delegation goes as far as its goes. It works on an everyday basis along with moderate conflicts and along with perhaps moderate failures of the CB. Big failures regarding especially the CB's supervision of (big) banks will again be bounced back to the state (see $7 \S 9$ ).

\section{$7 \S 8 \quad$ The objective of reaching creeping inflation}

Reaching creeping inflation (euphemistically called 'price stability') is a necessary condition for the accumulation of capital (cf. $\left.{ }_{4} \mathrm{D}_{3}\right)$. The state tends to encode this objective and to delegate its execution to the Central Bank. Creeping inflation should prevent the economic stagnation associated with the combination of generalised price competition and speeded up technical change (4§9). Because price competition is the impetus for the objective of creeping inflation, this matter will be treated in Chapter 9 on 'the imposition of competition'.

A side effect of the stagnation-prevention impetus to creeping inflation is that workers get one step (one year) behind in wage-bargaining, as priceinflation compensation is most often provided afterwards. I write that this is a side effect, but it may well be a co-objective of creeping inflation.

\section{$7 \$ 9 \quad$ Banking crises and the movement to 'too big to fail' banks}

Over-optimism of enterprises as accommodated by the banks' over-crediting make the banking constellation vulnerable to the failure of banks, and even to failures on a large scale, leading to a crisis of the banking constellation $(2 \S 10$; 
$2 \S 10-b)$. Banking crises and the associated recessions (Graph 2.11 in $2 \S 10-b$ ) have severely damaging effects on the capitalist economy. Nevertheless, in the history of the capitalist system until recently, these have not threatened the reproduction of the system. However, the 2008-12 crisis, followed by the 'great recession' aftermath, did pose such threat. ${ }^{5}$ One important factor contributing to it was the gigantic concentration of bank capital and the centralisation of banks from the 198 os. $^{6}$ This led to 'big' banks (so big, as we will see in Chapter 9 , that these are organisationally too complex to supervise in micro terms) and to so-called 'too big to fail' banks. Failure of such big banks tends to trigger a domino of failures of other banks, up to the collapse of the banking constellation and therewith tending to the collapse of the capitalist system as a whole. This implies that the $\mathrm{CB}$ and/or the state is/are enforced to save the banks that are too big to fail.

Some commentators take the view that for the saving of such banks the Central Bank could 'print' money. But given the principles of double bookkeeping, this is not the case. The CB can lend money, and when it lends money against bad loans this should be reflected in the CB's equity. Then there are only two possibilities: the state makes up for the equity deficit of the $\mathrm{CB}$, or the state settles the finance capital of the big bad banks (via finance capital 'injections' in some form or another, including via the form of take-over). In both these cases, the state is effectively the lender of last resort (not the presumed 'independent' CB). Directly or indirectly, this means that the state is 'tax levier of last resort'. Indeed, economic actors pay the price for it. To be sure, they pay not only the price of saving the banks, but also the price of the recessive or depressive effects of a banking crisis.

The allowance or non-allowance of the concentration and centralisation in the banking sector is ultimately a matter of regulation and supervision, and of the willingness of the state to put constraints on the mode of competition and

5 At the point of a threatening collapse, the state officials are constrained not to communicate this publicly, because that would have a self-reinforcing effect. Because of the severe threat of a collapse around 2008-12, a number of members of parliament were informed (as I was, when at the time I was a member of the senate of the Netherlands, as one of its financial spokespersons) though under the clause of strict confidentiality. Luyendijk writes in The Guardian: 'Herman van Rompuy waited until 2014 to acknowledge in an interview that he had seen the system come within "a few millimetres of total implosion".' In 2008, Van Rompuy was the prime minister of Belgium, and in 2009-14 the full-time president of the EU council of heads of government. https://www.theguardian.com/business/2015/sep/ 30/how-the-banks-ignored-lessons-of-crash.

6 By 2005, the assets of the three largest banks as a percentage of the assets of all banks reached $74 \%$ for the OECD-21 countries on average (see Appendix 9A, Graph 9.3). 
the mode of capital accumulation. Moreover, 'too big to fail' may apply not only to banks, but also to other key sectors (those on which a vast majority of actors is dependent whilst there is no ready substitute) such as the energy sector and the communications sector (currently ICT). Therefore this matter will be treated in Chapter 9 on 'the imposition of competition'.

\section{Division 3. The labour-capacity framework Accumulation-furthering regulation}

This division presents the second of the three main levers for the state's furthering of the conditions for economic growth (next to ${ }_{7} \mathrm{D}_{2}$ and ${ }_{7} \mathrm{D}_{4}$ ). The current division is also the sequel to $2 \mathrm{D} 2$ on the expansion of labour-capacity.

\section{$7 \S 10 \quad$ Minimum wage: the reproduction of the current labour population}

The state's maintenance of capitalist legal right, and generally its action radius, requires that it furthers the conditions for economic growth and hence the accumulation of capital $(7 \S 3)$. For these and all of its (non-)actions, the state must continuously seek legitimation in the compliance of social actors, particularly in that of, very broadly, the 'objective classes' of the 'capitalist and managerial class' (CMC) and the subordinated working class (SWC) $(6 \S 12)$.

A wage below at least a subsistence wage would result in labour shortage and impair the reproduction of the labour population. ${ }^{7}$ Whereas this is selfdestructive for enterprises, there are nevertheless insufficient forces within the economy preventing such self-destruction in at least the medium term $(7 £ 10-a$ below).

The state's furthering of the conditions for the accumulation of capital therefore requires it to impose a legal minimum wage, being at least a subsistence wage $(7 \S 10-b) .{ }^{8}$ At the same time a legal minimum wage infringes on capitalist economic rights, especially the extent of the employers' legal right to employ labour-capacity (6§11).

7 Malnutrition - as well as bad hygienic circumstances that tend to accompany it - affects first of all children and their death rates and hence the potential labour population within a time span of some 10 to 15 years.

8 When there are general social security provisions for the structurally unemployed (see $7 \mathrm{D}_{5}$ ), these may contingently be the effective benchmark for non-imposed minimum wages (in this case employers have to pay a wage at least equivalent to the level of these transfers - as was the case, e.g., in Germany until 2014). 
A substantial legal minimum wage is in the interest of the SwC (as always, within the confines of the capitalist system). Although in the perception of individual CMC actors it might go against their interests, it is nevertheless in their common interest, given the requirement of the reproduction of the labour population. For competitive reasons, an important general consideration for enterprises is that any minimum wage restrictions/constraints apply equally to all.

Regarding the potential conflict about this (amplified in $7 \S 11$ below), the delicate point is the level of the minimum wage. It might vary from minimum subsistence to one beyond some definition of a poverty line or a 'living wage' (each of these always includes a socio-cultural component $-7 \S 10-b)$.

$7 \S 10-a \quad$ Amplification. The labour population in the absence of a legal minimum wage

Recall that all of the exposition in this book is about the full-fledged capitalist system in general, independently of the contingencies of its particular historical stages (General Introduction). Mere subsistence wages were prevalent throughout the nineteenth century in the current 'strong' capitalist OECD countries (see Appendix 6A on these countries) and throughout the twentieth century in many other capitalist countries.

When there is unemployment (hence labour abundance), competition will tend to press down wages. This would affect the reproduction of the current labour population in case the wage is pressed down below the subsistence wage. That reproduction effect is not immediately actual. Rather, as indicated in the last but one footnote, malnutrition - as well as bad hygienic circumstances that tend to accompany it - affects first of all children and their death rates and hence the potential labour population within a time span of some 10 to 15 years. Co-depending on several macroeconomic conditions, the death rate process would ultimately give rise to labour shortage and a rise of wages to perhaps above the subsistence wage, which would have again a lagged effect on the death rates and so the labour population growth. (Cf. the labour populations theories of Classical Political Economy.) Although there are so 'equilibrating' forces, their long time span tends to produce stagnation rather than flourishing economic growth: ceteris paribus the labour population growth being the constraint. (It is remarkable that this matter plays no part in the conventional neoclassical economics on the labour market and the minimum wage in particular.) 
$7 \S 10-b \quad$ Amplification. Subsistence wage and legal minimum wage It is not obvious how a subsistence wage should be defined. Ultimately measures for it might be devised on the basis of interregional comparisons of death rates. In any case it includes a socio-cultural component, whence a definition by exclusively nutritional components is insufficient. Quite apart from these socio-cultural components, the subsistence wage should also include a component for the raising of children and for sickness. Similar difficulties apply for definitions of the poverty line (e.g. CBS/SCP 2013) or of 'decency' - a term adopted in Human Rights covenants and in ILO covenants (Biermans 2012).

Whereas these problems of definition are relevant for deliberations about a legal minimum wage (see also $7 \S 11$ ), the point of the main text $(7 \S 10$ ) is that the state is required to set some legal minimum wage, whatever it is (with the caveat set out in the last footnote).

\section{$7 \S 11$ Delegation to minimum wage commissions or councils}

A legal minimum wage infringes on the capitalist economic right to freely employ labour-capacity - the delicate point being especially the level of the minimum wage $(7 \S 10)$.

The potential social conflict about it threatens the legitimation of the state. Therefore the state tends to delegate the determination of the level of the minimum wage to minimum wage commissions or minimum wage councils. This is again an effort to purify the core administrative body of the state from conflict (cf. the purifying delegations presented in $6 \S 15$ and $7 \S 7$ ).

\section{$7 \S 12 \quad$ Temporary unemployment benefits}

- cyclical (temporary) unemployment benefits

The accumulation of capital develops cyclically (Chapter 5 ). To the extent that cyclical unemployment would result in a deprived - hence unfit or even aborted - echelon of labour reserve, enterprises would be deprived of a fresh valorisation potential in the upturn of the cycle. ${ }^{9}$ Therefore the state's objective of furthering the conditions for economic growth and hence the accumulation of capital $(7 \S 3)$ requires it to impose regulation on cyclical unemployment benefits. As the emergence of the downturn of the cycle is difficult to define, these benefits tend to be extended to lay-offs in general for a limited duration. ${ }^{10}$ It

9 (Cyclical) unemployment is a statistical uncertainty, and hence it cannot be insured; when it can, it is usually at high costs and for limited levels and duration.

10 Given that the downturn period of 'normal' cycles (those not particularly associated with banking crises) is some two years - the duration of these benefits would roughly extend to such a period. 
is contingent whether these benefits are paid out of taxation or - perhaps in part - specifically out of contributions by enterprises.

- sickness benefits

A similar argument applies for average 'normal' sickness of workers. ${ }^{11}$ Enterprises have no interest in immediately sacking these workers, or in their deprivation during a somewhat extended period of sickness. Therefore state regulation of sickness benefits is in the interest of enterprises (as well as of the workers), so providing equal conditions of capital accumulation. The level of these benefits is contingent. The same applies for their way of finance - in this case, however, the finance tends to be imposed on enterprises. (In terms of costs for enterprises this comes down to an extended minimum wage.)

For each of these benefits it applies that these are in the interest of the SWC as well as the смС. Again their level is the main source of conflict. Given the resolution of a minimum wage level $(7 \S 11)$, the level of the benefits above tends to be set at some percentage of the minimum wage.

\section{$7 \S 13 \quad$ Labour population growth}

Population policy might seem to be generally contingent. However, in face of the state's objective of furthering the conditions for economic growth and hence the accumulation of capital $(7 \S 3)$, population policy is a requirement in case of a foreseen structural labour scarcity. (Note that whereas $7 \S 10$ is about the reproduction of the current labour population, the section at hand is about long run labour population growth.)

Given some current population growth - and given some state of technical development - that population growth, and hence the labour population growth, ultimately operates as a limit on the accumulation of capital (cf. $2 \mathrm{D} 2$, especially the interconnections summarised in $2 \S 6$ and Figure 2.5). Recall that $2 \S 4$ posited labour population growth as a contingency. In terms of the method adopted in this book, this is still an open end. ${ }^{12}$

Given the population growth and the labour participation (see below), the available labour-capacity is determined by:

\section{- the length of the working day (or week)}

In case of structural labour scarcity, the state might relax the existing regulation on the length of the working day or week $(6 \S 14)$. This, however, is highly conflicting.

11 Average 'normal' sickness is distinguished from enduring disability to work (for the latter see $\left.{ }_{7} \mathrm{D}_{5}\right)$.

12 Recall the conclusion from $2 \S 4$, heading 1: 'It is a problem for capitalist enterprises that the reserve of labour is rather indeterminate and thus hard to control.' 
The available labour-capacity is also determined by:

\section{- occupational health and safety}

Equally conflicting would be for the state to relax the occupational health and safety regulation $(6 \S 14)$.

Given the status of the former two regulations, the available labour-capacity is next determined by:

\section{- labour participation}

The labour participation is the net effect of: first, the division of work within the household; second, the duration of formal education; and third, the retirement age. (1) The first of these is the most complicated as, in the case of families, it is largely a matter of, on the one hand, socio-economic culture and, on the other, the (non-)enforcement of multiple earning in face of the level of a single wage. Anyway, the state might stimulate multiple earning by, for example, tax reductions for the second earner. (2) A reduction in the duration of education conflicts with the enhancement of the labour-capacity required by enterprises (see below, $7 \S 14)$. (3) The contingency of a (perhaps enforced) retirement age has not been introduced (see $7 \mathrm{D}_{5}$ ). Should there contingently be old age/pension transfers, then the age of eligibility can be extended.

Given the status of the former three regulations, the available labourcapacity is finally determined by:

\section{- population growth}

Population growth is the net result of birth and death ratios. Regarding death ratios the state could adopt a wide arsenal of regulation ranging from traffic speed limits (cheap) to a public health service (expensive). The factors operating on birth ratios are more complicated. Nevertheless the state can use the instrument of child benefits to enhance population growth (perhaps by increasing - benefits beyond the second child). In this case the requirement is for temporary stages of child benefits, as long as the population growth requires to be enhanced.

$7 \S 13$-a Amplification. Importation of labour-capacity

Up to Chapter 11 the exposition is about a single isolated economy and state, or alternatively a borderless world economy and state. In case of a multitude of nations and states, labour scarcity regions might import labour-capacity from labour-abundant regions.

$7 \S 13-\mathrm{b} \quad$ Amplification. State expenditure for the regulation presented in $7 \S 10-7 \S 13$

All legislation and other regulation require state expenditure on legislation and supervision, as well as on authorities and commissions to which the state del- 
egates tasks. In comparison with all other state expenditure this is a minor part (see Chapter 10). Apart from that, the regulation of the minimum wage level ( $7 \S 10)$ does not require state expenditure (except for the state's own employment). However, temporary unemployment benefits may go along with state expenditure. The same goes for child benefits ( $\left.7 \S_{13}\right)$. Empirical information on the latter two is provided in ${ }_{7} \mathrm{D}_{5}$, Graphs 7.9 and 7.10.

\section{$7 \S 14 \quad$ Public education}

The state is required to further the conditions for economic growth $(7 \S 3)$. One means for this is the enhancement of the quality of the labour-capacity needed by enterprises. The state may further this by way of public education (synonymous with state education), or more generally by state-funded education. There are several (contingent) ways of organising this (see $7 \S 14-b)$.

Up to this point, the exposition was restricted to state expenditure on legislation, on the maintenance of legal right, and on the quantity of the labourcapacity. State-funded education introduces a qualitatively new moment into the exposition, both in terms of the type of state expenditure (the quality of the labour-capacity), and in terms of the amount of state expenditure (see $7 \S 14-d$ ). Whereas state-funded education furthers the conditions for the accumulation of capital (as contingent on the stage of technical development) a trade-off between its costs and benefits is difficult to determine even in terms of exclusively monetary objectives.

Public education is in the interest of enterprises and the CMC, whilst it is certainly also in the interest of the swC. (On the classes of СMC and SWC see $7 \S 10$ and $6 \S 12$.)

$7 \S 14-\mathrm{a} \quad$ Explication. Necessity of public education and of all the moments of ${ }_{7} \mathrm{D}_{3}$ and ${ }_{7} \mathrm{D}_{4}$

Public education by itself is not necessary to the 'phantom' of a capitalist economy that might be supposed to stand on itself (even if without public education, profits and the rate of accumulation of capital would slacken). It is, however, necessary to the capitalist system to the extent that the furthering of the conditions for economic growth is a necessary objective for the capitalist state $(7 \S 3)$. However, the dodgy question is not about the necessity, but rather about the degree. The latter is inevitably a matter of opposing interests, choices and conflict resolution in practice. A similar remark applies to all the moments of ${ }_{7} \mathrm{D}_{3}$ and ${ }_{7} \mathrm{D}_{4}$. 


\section{7§14-b Amplification. Reason for state-funded education and the contingent main ways of organising it}

Were all formal education left completely to the market, then the education would tend to be restricted to high income earning families. The resulting under-education of the majority of the workers would limit the possible implementation of new techniques of production. On the job education and training of general skills that can be used in any other job secure rents for enterprises that abstain from providing this general education and training. Therefore it is in the interest of enterprises that education is provided, or at least funded, collectively. ${ }^{13}$

The specific way of doing this is contingent. One possibility is that all formal education is provided by profit-driven private institutions (i.e. enterprises), with the state subsidising the pupils and students via grants. The efficiency of such a system is doubtful. Another possibility is that the state funds the educational institutions, requiring these institutions to provide the education for free.

All this tends to be combined with regulation of compulsory education up to some age. The age of compulsory education is contingently related to the state of technical development. It is also contingent whether, and to what degree, the state funds higher education beyond the compulsory age.

Equally contingent is whether, on top of the free education, the state provides subsidies, grants or loans for livelihood during the education. Should the state not provide means for livelihood during especially the duration of the compulsory education, then the average equivalent is required to be part of either the minimum wage $(6 \S 7)$ or there should be - more directly - child benefits to cover this.

Note that - as always - the argument here and in the main text is not about morals, and in this case about any emancipatory aspects of free education. The 'enhancement of the labour-capacity required by enterprises' $(7 \S 14)$ does not univocally imply that the corresponding education is emancipatory (see also $2 \S 7$ about compliance with the objectives of the enterprise).

13 Ultra-free market proponents question this. In an article in the American Economic Review, Blankenau, Simpson and Tomljanovich (2007) suggest that 'the inability of some studies to find a robust relationship between public education spending and growth may reflect a failure to properly account for the method of finance'. 
$7 \S 14-c \quad$ Amplification. Development of the years of average formal schooling, and indicators of the current distribution of schooling: case of the OECD-21

(See Appendix 6A on the mere illustrative status of the OECD-21 data, here and in the rest of this chapter.) Graph 7.5 shows data of the development of the average number of years of formal schooling (not particularly public schooling). For the average of 21 current OECD countries, we see an almost linear increase in the number of years of formal schooling from 1870-1950, followed by an accelerated increase from 1950-80. After 1980 the increase somewhat flattens off. For the distribution we see a sharp decline in the skewedness from 1870-1920 and a considerable decline after 1930. (The Gini measure for the distribution is on the scale of o-10o: the number o indicating complete evenness of the distribution, and the number 100 maximal skewedness - all education devoted to one person.)

GRAPH 7.5 Years of formal schooling and distribution of schooling 1870-2010; average of 21 current OECD countries ${ }^{14}$

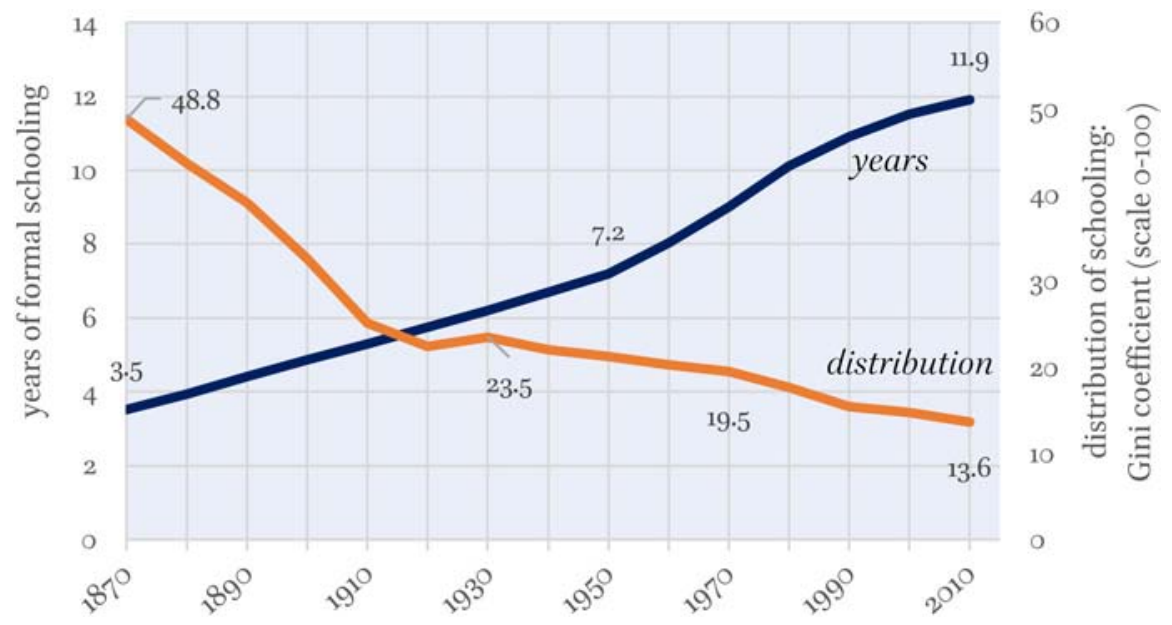

DATA SOURCE: Clio Infra (accessed 27 February 2016). See Appendix 7 A, under '7§14-c', for more information on the data

7§14-d Amplification. State expenditure on education: case of the OECD-21.

Graph 7.6 shows data on state expenditure as a percentage of GDP from 18702014 , for the average of up to 21 current OECD countries. There are some gaps in

14 These are the 'OECD-21' (see Appendix 6A). 
these data (these are interpolated), but, as far as I know, we have no more especially for the period prior to 1960 (see Appendix $7 \mathrm{~A}$, under ' $7 \S 14-\mathrm{d}$ '.) Note that 'general government' is a (statistical) category denoting all levels of government (the central plus the various levels of the local ones).

GRAPH 7.6 State expenditure (general government) on education, 1870-2014, in $\%$ of GDP; average of up to 21 current OECD countries

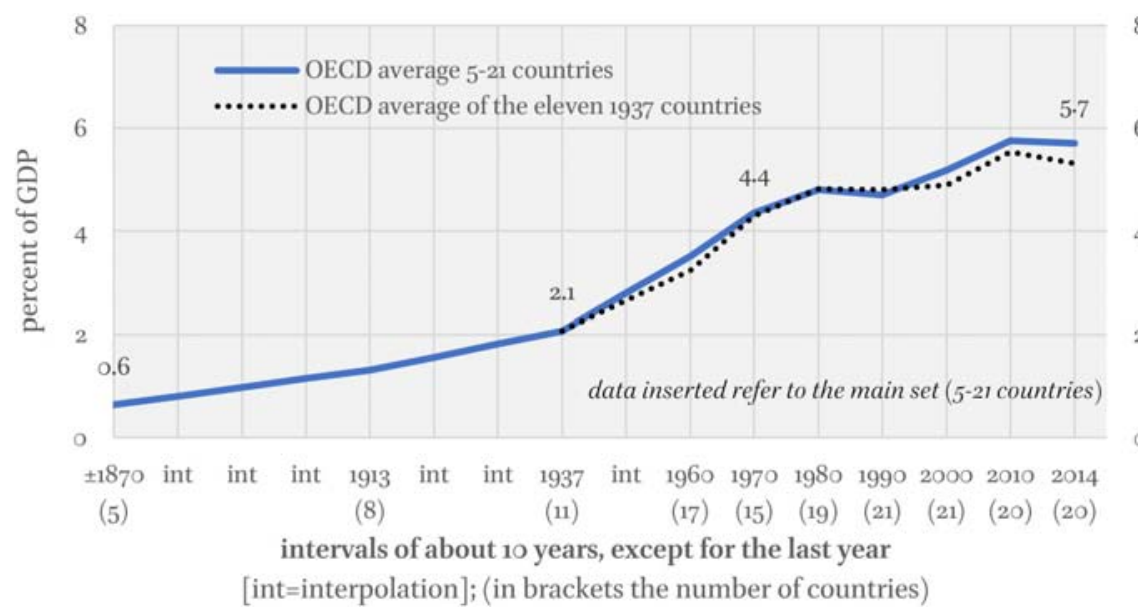

DATA SOURCES: 1870-196o (Tanzi and Schuknecht 200o, Table II.5); 1970-2014 (UNESCO institute for statistics, May 2017 release, accessed 27 December 2017). See Appendix 7 A, under ' 7 \$14-d', for more information on the data

It can be seen from Graph 7.6 that already in 1870 there was, on average, a considerable state expenditure on education of $0.6 \%$ of GDP, moving to $2.1 \%$ in 1937. After a quite steep increase between 1937 and 1970 (to 4.4\%), the degree of increase flattens off in the decades thereafter.

$7 \S 14-\mathrm{e} \quad$ Amplification. Impact of varying number of countries in historical datasets

In order to show the possible impact of the scarce number of data for earlier years in terms of number of counties, most of my figures show graphs for separate series of countries - in the main text or in the statistical appendix of a chapter. See, for example, the two series in Graph 7.6. There we see that the data for the 11 countries of 1937 approximate the 17 of 1960 and the 21 afterwards, so that it may be concluded that the 1937 figure is probably a reliable proxy for the total. 


\section{Division 4. The infrastructural framework Accumulation-furthering regulation}

This division presents the third of the three main levers for the state's furthering of the conditions for economic growth (next to ${ }_{7} \mathrm{D}_{2}$ and ${ }_{7} \mathrm{D}_{3}$ ).

\section{$7 \$ 15$ Infrastructure}

\section{- Infrastructural networks}

There is a category of (potential) economic activities - called infrastructural that substantially does or would raise the macroeconomic productivity of labour and so does or would raise macroeconomic surplus-value (integral profit), but that nevertheless either cannot microeconomically be profitably produced by enterprises, or, if it could, would generate a monopoly. ${ }^{15}$ Most often these concern very costly networks. That is, networks for the transport of commodities and of waste, including critical nodes for the former. More specifically, networks for the transport of vehicles (for people and commodities), for commodities (the latter including communication/information, energy) and for waste (including sewers).

\section{- State engagement in infrastructural networks}

To the extent that these productivity raising infrastructural activities are not undertaken by enterprises without generating a monopoly, the state's objective of furthering the conditions for economic growth and hence the accumulation of capital $(7 \S 3)$ requires it to engage in these.

In addition, though more controversial than the former, the state might engage in infrastructural activities that are, or could be, undertaken by private enterprises, when these can be produced at a lower cost collectively than competitively. Nevertheless such engagement is in line with the objective of increasing the macroeconomic tax base.

The state's engagement in the provision of networks can be undertaken in various ways. Networks may be produced, maintained and owned by the state. Alternatively these are owned by the state though via procurement produced and maintained by enterprises. In some cases another possibility might be to temporarily license the provision to enterprises perhaps via procurement. Apart from this last possibility, state engagement in infrastructural activity considerably raises the state expenditures and the amount of taxation (as with

15 The non-profitability might be merely contingently the case. Technical development might change the tables such that a formerly non-profitable activity may become profitable. Apart from that, Chapter 9 sets out why the state tends to put restrictions on monopolisation. 
education), though - in face of the effect on productivity, costs and growth not necessarily the tax rates.

\section{- Infrastructural supply (plant)}

In many cases the supply of the commodities transported via infrastructural networks has itself a so-called infrastructural character tending to (regional) monopoly or oligopoly (for example, water resources, mass energy generation, communication, train connection). When in addition there are no ready (regional) substitutes for these, the state cannot allow the possible bankruptcy of the supplying enterprises - that is, without jeopardising the reproduction of the (regional) economy. Because 'too big to fail' implies private profits combined with social losses, this may be a reason for state ownership of the infrastructural supply.

$7 \S 15$-a Amplification. State expenditure on infrastructure, 1870 to current: case of the OECD-21

For the OECD countries, internationally more or less homogenous data for state expenditure on infrastructure are only available from 1995. However, for state gross investment expenditure (general government) long run data are available. Therefore I use a major fraction $(57.5 \%)$ of the latter as an approximation for the infrastructure expenditure. In Appendix $7 \mathrm{~A}$ (under $7 \S 15$-a) I provide an underpinning of this proxy, by relating it to the after 1995 infrastructure data.

In this perspective Graph 7.7 shows data on state expenditure (general government) on gross investment for the average of up to 21 current OECD countries, from 1870 to 2015. Judging from the data available, it can be seen that from 1870 (investment at about $2 \%$ of GDP) there is a steady increase until 1970. In the six decades thereafter the average for investment decreases quite substantially, reaching in 2015 a GDP share of just below that of 1920 .

Thus the expenditure on infrastructure (as approximated by $57.5 \%$ of gross investment) moved from $1.2 \%$ in 1870 to a top of $3.2 \%$ in 1970 , and then gradually decreased to a GDP share of $1.9 \%$ in 2015 . One cause of the decrease is the substitution of state ownership for private ownership via licenses as indicated in the main text of $7 \S 15$. 
GRAPH 7.7 State expenditure (generalgovernment) on gross investment, 1870-2015, average of up to 21 current OECD countries

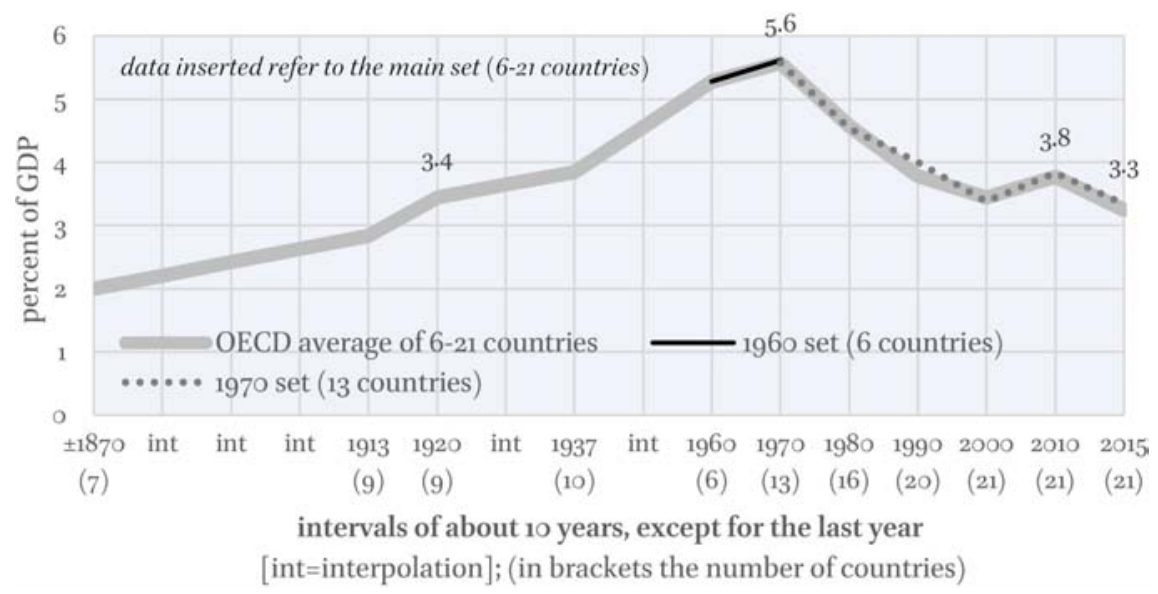

DATA SOURCES: 1870-1937 (Tanzi and Schuknecht 200o); 196o-2015 (OECD Economic Outlook database 2017-2, June, accessed 27 December 2017). See Appendix $7 \mathrm{~A}$, under ' $7 \S 15$-a', for more information on the data

\section{$7 \$ 16 \quad$ Fundamental technology research}

Fundamental technology research (in contradistinction to technique and applied technique development) is unlikely to be carried out by enterprises on a considerable scale. Nevertheless fundamental technology research is indispensable for applied research and technique development. Given the state's objective of furthering the conditions for economic growth and hence the accumulation of capital $(7 \S 3)$, the finance by the state of this fundamental research is perhaps not absolutely necessary, but it is (at least today) de facto considerable. The dodgy question for the state is how much and on the basis of what criterion (there does not seem to be such a criterion).

7§16-a Amplification. The state's fundamental technology research In a study that focuses on research and development (R\&D) after wwII, Mazzucato $(2011)^{16}$ indicates that for the year 2008 in the USA, business companies accounted for $67 \%$ of total R\&D expenditure. However, regarding the basic $\mathrm{R} \& \mathrm{D}$ this was $18 \%$, the rest was undertaken by the Federal government $(57 \%)$, universities and colleges (15\%) and other non-profit institutions (11\%). (See Figures 3 and 4 in Mazzucato 2011, pp. 51-2.) She shows that the state is 'a lead-

16 See also Mazzucato 2013. 
ing agent in achieving the type of innovative breakthroughs that allow companies, and economies, to grow' (p. 18). It has been 'the state not the private sector that has kick-started and developed the engine of growth, because of its willingness to take risk in areas where the private sector has been too riskaverse' (p. 23). More specifically she shows that the technological revolutions of the computer industry, the Internet, the pharma-biotech industry, nanotech industry and many more are the result of the 'leading role of the state' (p. 20; and pp. $7^{6 \mathrm{ff} .) .}{ }^{17}$ (In the terminology of Chapters 1-2, I call the fundamental research 'technology research' and the research regarding the application of technology 'technique research'.)

\section{Division 5. The social security framework \\ The indeterminate degree of social security transfers in face of the required compliance of subordinated labour}

The legitimation of the state in the compliance of the vast majority of actors $\left(6 \mathrm{D}_{3}, 6 \S 5\right)$, grounds the state-granted economic rights $\left(6 \mathrm{D}_{2}\right)$ at an abstractgeneral level. Inherent to the latter, this legitimation in compliance is systematically a high-level determinant for all of the more concrete conditions of existence presented in the later exposition. (In this there is an analogue with the monetary-value dimension - 1D2.) More concretely, the legitimating compliance is engendered in the compliance of categories of actors that have a particular (non-)interest in the existence and outcomes of the capitalist system (recall the reference to the two very broad objective classes of the capitalist and managerial class (CMC) and the subordinated working class (SWC) in 6\$12).

In this perspective the current division - which focuses on the compliance of the SWC - grounds $6 \mathrm{D}_{3}$, as well as all the later conditions of existence presented so far (see Scheme 7.1).

Recall that in $6 \S 17$ a distinction was made between 'allowance rights/provisions' and 'positive rights/provisions'. In terms of the broad category of 'existence rights', and especially 'positive existence rights/provisions', the current division is a continuation from three moments presented in ${ }_{7} \mathrm{D}_{3}$ (those of the minimum wage, temporary unemployment benefits and child benefits). These

17 Because I will not return to this matter in Chapter 11 - when I introduce multiple nations and multiple states - it may be noted that specific states may specialise in particular branches of fundamental research. The R\&D workers, especially those of the large enterprises carrying out applied research and development, must be equipped to absorb the fundamental research wherever it is located (see WRR 2013a and 2013b). 
latter, however, serve primarily the labour-capacity requirements - the 'positive rights/provision' being a corollary. However, the moments presented in the current division are 'self-standing' in face of the legitimation referred to.

\section{$7 \S 17 \quad$ Legitimation: compliance-dependent social security transfers}

1 Seeking legitimation in the compliance of the vast majority

For its actions and non-actions the state inevitably has to seek and gain legitimation in the compliance of not just a majority but the vast majority of actors $(6 \S 5 ; 6 \S 18)$. Given that the subordinated working class constitutes the vast majority, the state must necessarily seek their compliance. ${ }^{18}$ This may require, first, minimum wages that are substantially higher than subsistence wages $(7 \S 10)$ and, second, compensation for actors out of work as well as for expenditures that should be covered by a 'decent' wage but are not.

Such compensations regard these actors' 'existence security', or, as it is commonly called (perhaps less heavily laden), 'social security'. These are necessary ${ }^{19}$ However, their level is contingent in the sense that compliance is dependent on a contingent degree of conflict or perhaps resistance in case of non-materialisation of sufficient compensations.

In face of this 'level-contingency', this section outlines a social security framework: first, the main prevailing categories of social security, and secondly, the legal forms in which these can be provided. For 'compensation' I adopt the common term 'transfer'.

$2 \quad$ Categories of social security transfers

There are six categories of social security transfers, which can be divided into two groups.

A. Out of work transfers, specifically regarding:

- Unemployment in general - that is, transfers for structural unemployment, next to the temporary unemployment benefits presented in $7 \S 12$.

- Incapacity (disability) - that is, incapacity during the regular working life.

- Old-age disability or exemption to work (pensions).

18 From research by Mohun (2016) for the USA 1918-2012, it can be inferred that during this period on average, the subordinated working class made up $82 \%$ of the total. (See also $2 \S 15$-a.)

19 Even in the period $1880-1920$ there were some of these, the state expenditure amounting from 0.4 to $0.9 \%$ of GDP (average of available data of current OECD countries) - see further $7 \S 17$-a. In this early period, poor relief by especially religious institutions was dominant. 


\section{B. Expenditures related transfers, specifically regarding:}

- Health (cure \& care) - these can be transfers, but can also be provided in kind;

- Child related in general - next to transfers required in case of foreseen scarcity of the labour population $(7 \S 13) .{ }^{20}$

- Housing - these are housing market dependent, and in fact dependent on whether the minimum wage, or the transfers under $\mathrm{A}$, are sufficient to rent a house.

\section{3 \\ Legal forms of social security transfers}

\section{A. Protection of the poor}

Social security transfers can be granted in the form of provisions for the poor. This requires determination of 'the' poverty line. For some ideological stances such provisions clash with their 'free market' principle that there should be no such thing as a 'free income' - an income not deriving from either work or property. The state can take such a stance into account, but ultimately it has to seek and gain the 'vast majority' compliance.

\section{B. Generalised social security transfers}

The sting seems somewhat taken out of these ideological complaints when the transfers above (apart from housing) are granted to all (the poor and the rich). Such a constellation has also been defended on the basis of the argument that it increases the general public support for these. ${ }^{21}$ Quite apart from ideological and supportive arguments, generalised social security prevents stigmatisation of the poor. However, the general effect is also (as with a so-called basic income) the pumping around of large sums of money, increasing state expenditure and taxation (directly or in the form of so-called social insurance contributions).

Within each of these two legal forms (the poor or generalised) there are again two legal forms for these: the form of legal rights and the form of legal provisions. In practice their main difference is that legal provisions are easier to cut back than legal rights once the latter's level has been determined.

The right-hand side column of Figure 7.8 provides a summary of the previous two subsections. Amplification $7 \S 17$-a provides empirical information on social security expenditures.

20 Child benefits can also be defended on the basis of equity arguments: everybody is free not to have children; those who have children are rewarded (bought off) for providing the future generation.

For example, in the Netherlands. 


\section{$4 \quad$ Social security transfers and surplus-value}

The legitimation of the state - as based on vast majority compliance - requires social security transfers. Because the legitimation of the state is a sine qua non for the existence of the capitalist system, these transfers are an indirect condition for the accumulation of capital.

FIGURE 7.8 Legal forms of regulation of production and of existence security

\begin{tabular}{|c|c|c|}
\hline Regulation of production & \multicolumn{2}{|l|}{ Regulation of existence security } \\
\hline o form of legal allowance rights & o form of legal positive rights & \\
\hline level: compliance dependent & $\begin{array}{l}\text { level: at least subsistence; further } \\
\text { compliance dependent }\end{array}$ & \\
\hline \multirow{5}{*}{$\begin{array}{l}\text { - } \text { consumer protection }[6 \S 14] \\
\text { - } \text { environment protection }[6 \S 14] \\
\text { - labour protection (safety, time, health) }[6 \S 15]\end{array}$} & $\begin{array}{l}\text { (regulation labour-capacity market) } \\
\text { - minimum wage }[7 \S 10]\end{array}$ & \\
\hline & $\begin{array}{l}\text { (regulation labour-capacity market) } \\
\text { - } \quad \text { temporary unemployment benefits }[7 \S 12] \\
\text { - } \quad \text { temporary sickness benefits }[7 \S 12]\end{array}$ & \multirow{4}{*}{ 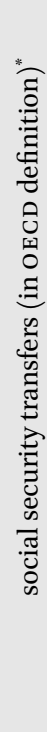 } \\
\hline & $\begin{array}{l}\text { o form of protection of the poor; OR } \\
\text { o form of general regulation. } \\
\text { AND } \\
\text { o form of provisions for existence; OR } \\
o \text { form of legal positive rights to existence. }\end{array}$ & \\
\hline & level for all: compliance dependent & \\
\hline & $\begin{array}{l}\text { - } \quad \text { child related transfers }[7 \S 13]^{\dagger \neq} \\
\text { - } \text { health (cure \& care): transfers or provisions } \\
\text { - } \\
\text { - } \text { structural-unemployment transfers } \\
\text { - } \text { old-age transfers } \\
\text { - } \\
\text { incapacity (disability) transfers } \\
\text { housing transfers (or provisions in kind) }\end{array}$ & \\
\hline
\end{tabular}

$\dagger$ Anyway required in case of foreseen scarcity of labour population ( $\left.7 \$_{13}\right)$.

‡ In Graph 7.9 these are covered under 'family'.

* The exposition in Chapter 7 makes a systematic distinction between labour-capacity related transfers (top of figure) and pure compliance related transfers. In the OECD categories this distinction is not made.

In effect, some of the appropriated surplus-value that flows to the capitalist and managerial classes CMC is merely handed back to pay for, mainly, the categories of health, old age and incapacity transfers (Graphs 7.9 and 7.10). 'Some': a 
considerable part of these transfers are paid out of gross wages - in the form of social security contributions (see also Chapter $8,8 \S 9$ ). Further, because of the (intertemporal) redistributive effects of social security from high to low incomes, savings tend to mitigate, which affects the validation of surplus-value positively (Chapter 3 , esp. $3 \S 3$ and $3 \S 1$, and further Chapter 8 ).

$7 \S 17-\mathrm{a} \quad$ Amplification. State expenditure on social security: case of the OECD-21

This amplification presents two graphs of data of state expenditure on social security: a detailed one for the period 1980-2010, and an aggregate one for the period $1880-2015$.

For the 'OECD-21' detailed internationally consistent data for social security expenditure are only available from 1980 (detailed, that is, along the categories distinguished in the main text of $7 \S 17$ ). These are shown in Graph 7.9, along with the average rate of unemployment in that period.

GRAPH 7.9 State expenditure (generalgovernment) on specific categories of social security transfers 1980-2010, in \% of GDP; averages of 19-21 oECD countries

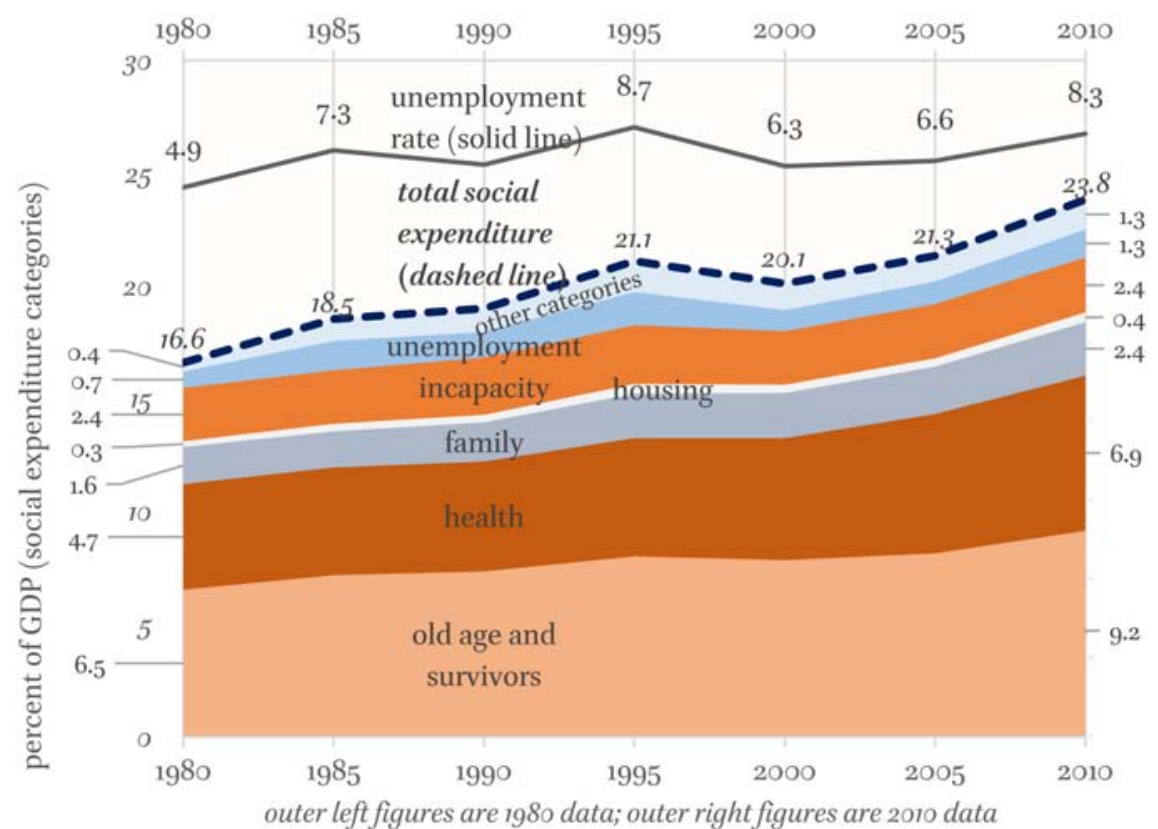

(in percent GDP)

DATA sources: Area charts: oecD, database 'Social Expenditure; Aggregated data (socx)'. Unemployment rate: OECD database. (All downloaded in December 2017.) See Appendix $7 \mathrm{~A}$ under $7 \S 17$-a for data details 
It can be seen that in this period there are upward trends in the three categories at the bottom of the graph - some of the categories at the top of the graph are in part related to the unemployment rate.

Graph 7.10 shows aggregate data for state expenditure on social security from 1880 for the current OECD-21. It can be seen that after a moderate increase from 1880 to 1930 (data for 1940 and 1950 are lacking), there is a rather steep increase until 1990 - the increase bending off afterwards. (It can also be seen that the trend is not very sensitive for the 17 or 21 countries in the data set.) $)^{22}$

GRAPH 7.10 State expenditure (general government) on social security $1880-$ 2015, average of up to 21 current OECD countries

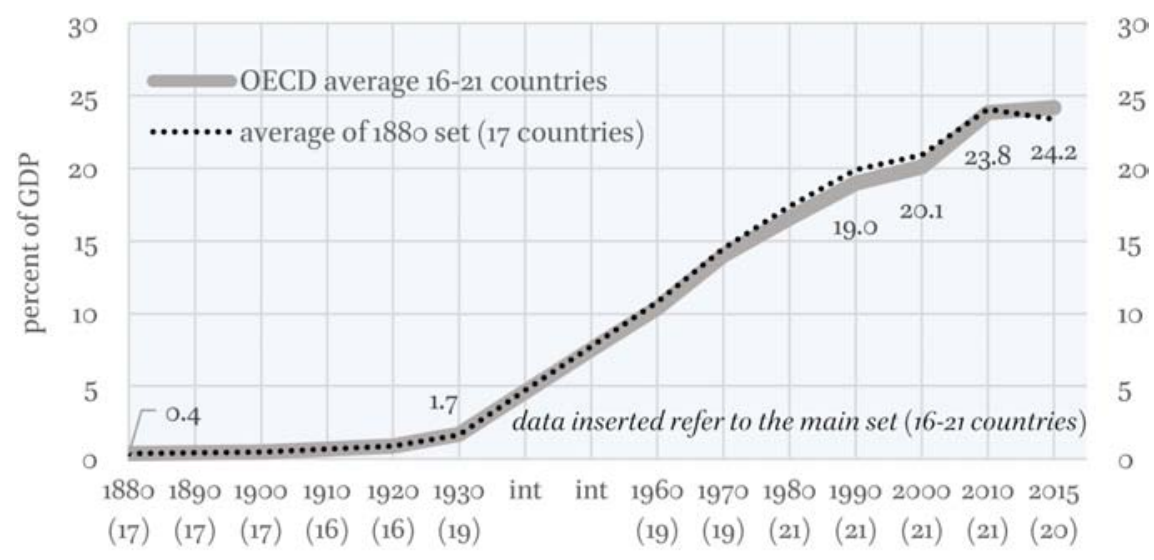

10 year intervals, except for the last year

[int=interpolation]; (in brackets the number of countries)

DATA SOURCES: 1880-1970 (Tanzi 2011, Table 1.2);1980-2014 (OECD, dataset Social Expenditure Aggregated data, extracted 27 December 2017) ${ }^{23}$

Total state expenditure (all categories) will be systematically introduced in Chapter 8. Anticipating that, Graph 7.11 already puts social expenditure in the perspective of the total. It can be seen that from 1920 (and for the data available) social security expenditure developed steadier than total state expenditure.

22 The OECD has also collected data on 'mandatory private social expenditure' (available for $9^{-15}$ countries of the OECD-21). This expenditure, although in quantity moderate, increased gradually from on average $0.7 \%$ of GDP in 1980 to $1.0 \%$ in 2011 . On these mandatory private expenditures, see Adema, Fron and Ladaique 2011.

OECD data available at: http://stats.oecd.org/index.aspx?DatasetCode=SOCX_AGG. 
GRAPH 7.11 Social security expenditure and total state expenditure (general government) 1870-2015 in \% of GDP; averages of up to 21 current OECD countries

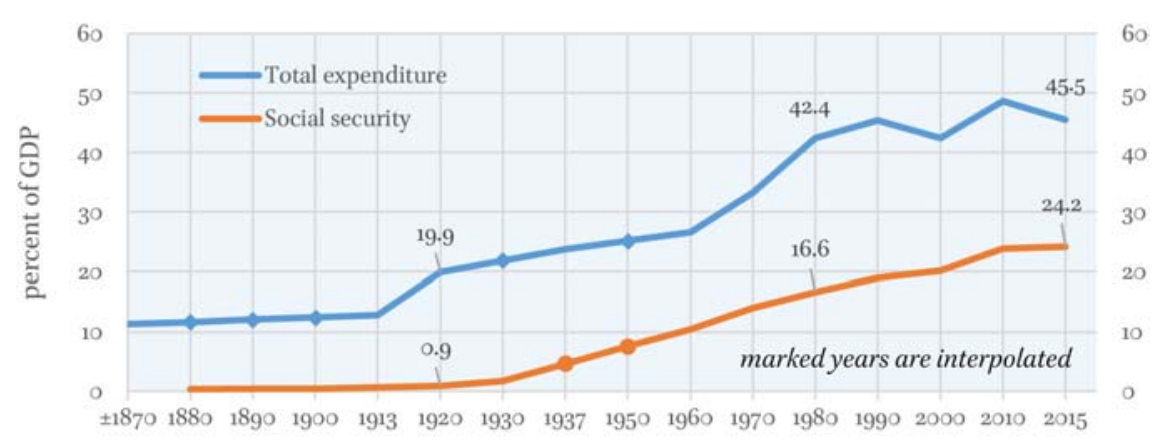

intervals of about 10 years, except for the last year

DATA SOURCES: (1) Social security: see Graph 7.10. (2) Total expenditure: 1870-1937 (Tanzi and Schuknecht 200o); 1960-1980 (Castles 2006); from 199o onwards (OECD Economic Outlook database November 2017, details are provided in Chapter 8: Graph 8.2 and Appendix 8A)

$7 \S 17$-b Amplification. (In-)decent outcomes

Recall that the exposition, in all of Part Two, is primarily one in terms of effects of the state, rather than the motives of agents of the state $(6 \S 4-a)$. It might be argued that even if social security expenditure grounds the state's legitimation, the effect - gradually from 193 o onwards - is an increasing 'decency'. This is correct. ('Decency' is a term used in the 'human rights' discourse, and I am aware that this is a moral or perhaps an ethical term.) However, such an observation and judgement might equally be formulated as a decreasing 'indecency', in which case the perspective on the total is different, namely one of indecency. This is relevant because, as argued in the previous sections of Chapters 6 and 7 , the state de facto keeps the capitalist system going.

7§17-c Amplification. Aggregate demand effect

Although it is not the impetus for social transfers, we will see in Chapter 10 that these transfers have the important side effect of mitigating the amplitude of the business cycle (to be sure, the latter cannot be read off from Graph 7.11 as it shows shares in GDP, not fluctuations in GDP). 


\section{Division 6. Separation of the state's administrative and judiciary branches}

Divisions 6 and 7 present the legitimation of the state from a perspective very different from that of Division ${ }_{5}$. Both ${ }_{7} \mathrm{D} 6$ and ${ }_{7} \mathrm{D}_{7}$ apply to the continuously reappearing conflicts of the content of legislation and other regulation, that is, the content of the seven regulative frameworks presented so far: capitalist economic rights $\left(6 \mathrm{D}_{4}\right)$, allowance rights to existence $\left(6 \mathrm{D}_{5}\right)$, public security (6D6), money and banking $\left({ }_{7} \mathrm{D}_{2}\right)$, labour-capacity $\left({ }_{7} \mathrm{D}_{3}\right)$, infrastructure $\left({ }_{7} \mathrm{D}_{4}\right)$, and social security $\left.{ }_{7} \mathrm{D}_{5}\right)$.

We will see in the following two divisions that the state seeks to mitigate the resulting conflicts, by institutional separations within the body of the state. The current division presents the separated off judiciary - separated from the main administrative body of the state.

\section{$7 \S 18$ Arbitration and sanctioning - legitimising assignment to a separated off Judiciary, as a separation-in-unity with the main body of the state}

It was indicated in Chapter 6 that the grounding of legal right requires the state to be the arbiter and sanctioner of deviations from the law (6\$9).

Arbitration often entails an interpretation and/or a concretisation of the law. This interpretation or concretisation may not be similar to the understanding of the law by the prosecuted actor. The sanctioning in this case conflicts with the actor's sense of justice.

This is even further at issue for the state's arbitration and sanctioning in case of conflicting rights. Conflicts are especially delicate when the sources of property are in dispute.

In all cases of conflict and senses of injustice, the state's reference to the (putative) general interest (6§6) and its (putative) impartiality $(6 \S 7)$ tend to erode. Thus the necessary grounding of legal right at hand (i.e. arbitration and sanctioning) may erode the legitimation of the state $(6 \S 5)$.

Therefore, in order to mitigate these erosive effects, the arbitration and the sanctioning of deviations from the law, tends to be assigned to a particular separate institution of the state: the judiciary. In this way the main body of the state - that is, its administrative branch (the latter being the unity of the legislative and the executive branches) - 'purifies' itself from conflict. Note that this assignment entails a higher degree of purification than, the alternative of, delegation (see $7 \S 18-a)$.

Inevitably, however, even if the judiciary is so split off from the administrative branch of the state, it is nevertheless a branch of the state as a 'separation- 
in-unity' within the state. (See Scheme 7.17.) This, it being a branch of the state, is also how it is experienced by most actors.

SCHEME 7.12 Arbitration and sanctioning as assigned to the separate Judiciary: separation-in-unity with the state's main body
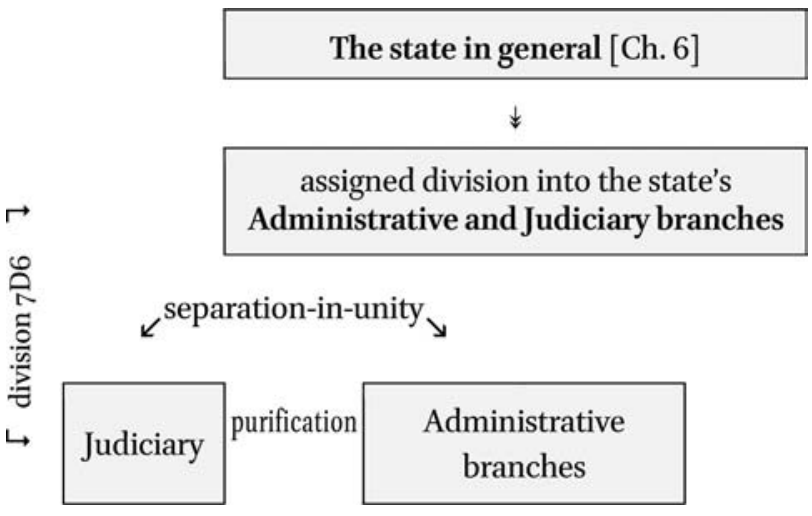

Legend

$\Downarrow$ grounding

$7 \S 18-\mathrm{a} \quad$ Explication. Degrees of purification: assignment versus delegation A distinction is made between the assignment and the delegation of state functions to separate bodies. Assignment regards a separation of activities within the state (separation-in-unity) without there being a subordination - in principle at least. With delegation $(6 \S 15,7 \S 7,7 \S 11)$ there is a relationship of subordination - ultimately the state remains responsible for what it delegates, though at distance and most often in a complicated manner. In terms of types of law: an assignment tends to be enacted at the level of the constitution, whereas a delegation tends to be enacted at the level of an ordinary law.

Although both assignment and delegation serve to protect the main body of the state from legitimation-eroding conflicts, their difference in terms of (non-)subordination implies different degrees of purification (a higher degree in case of assignment).

$7 \S 18$-b Amplification. Purification from conflict versus 'separation of powers'

The exposition of the judiciary in $7 \S 18$ is one from the point of view of the state and its concern to gain legitimating compliance $(6 \S 5)$ by (putatively) positing itself above and outside the opposing particular interests $(6 \S 7)$. The judiciary is 
separated off because arbitration and sanctioning by the state itself might have a negative effect on the compliance.

This exposition is very different from arguments about this separation in terms of separation of powers (as in Montesquieu's Trias Politica) - the latter being an argument from the point of view of the non-state actors ('subjects'). Whereas the purification seems necessary, a separation of powers may merely contribute to a moral ideal (one that I would not want to underrate).

However, in each case (purification and separation of powers) the separation requires a contingent institutionalisation that itself may not be unproblematic. Think for example of the appointment of judges by some institution of the state (e.g. by the presidency or a minister of justice or parliament), which muddles the separation. ${ }^{24}$ Further (and perhaps related), in everyday life many actors do have the feeling that the judiciary is an extension of the state. That feeling by itself seems correct - in any case it is covered by the term 'separationin-unity'.

As indicated, the argument in $7 \S 18$ is one from the point of view of the state so as to protect its legitimation - rather than a normative one from the point of view non-state actors. This is in line with all of the exposition in this book, which abstains from normative arguments and from morals (6\$4-a). Having indicated this, it may be noted that for the rest of the exposition not much hinges on it. In each case the relevant actual effect is the separation-in-unity between the state's Administrative and Judiciary branches.

\section{Division 7. Separation of the state's administrative and deliberative branches}

This division presents the 'Deliberative'. (I could have used the term 'parliament' if, today at least, this would not have the direct connotation of being a legislative, a function that I do not exclude, but that I would want to keep hanging for the time being.) The Deliberative is a second (and last) legitimating body within the state. As with the Judiciary, the Deliberative purifies the main body of the state from conflict, and again it constitutes a separation-

24 I am prepared to take small or large scale dismissals of part of the Judiciary as contingent aberrations. Take the case of Turkey in 2016, this country being a developed capitalist nation that forms part of the OECD from 1961. To be sure: within the systematic exposition of this book this is contingent because it is generally not necessary to the reproduction of the capitalist system. 
in-unity with the latter. Again this separation tends to have the character of an assignment (rather than delegation). The legitimation reasons for the Judiciary's separation off are rather straightforward, and it is most often also clear what is being assigned. In the case of the Deliberative the legitimation reasons are less straightforward, and the same applies for what is being assigned. This makes that the current separation requires more space than that of the judiciary.

The first few sections of this division $(7 \S 19-7 \S 22)$ present the four main areas of conflict for the action of the capitalist state that are explicit or implicit in the previous exposition. These conflicts seem insurmountable for the legitimation, and hence the existence, of the state as institutionalised in the exposition so far $\left(6 \mathrm{D}_{3}\right.$ and $\left.7 \mathrm{D} 6\right)$. The last section presents the separation within the body of the state referred to above, one that should overcome this problem of legitimation $(7 \S 23)$.

\section{$7 \S 19 \quad$ Taxation and the overriding of property right}

The material existence of the state requires it to appropriate means from the economy by taxation. Taxation so grounds the state's maintenance of legal right, including legal property rights. At the same time, taxation overrides property right $(7 \S 2)$.

Thus it appears that legal full property right - in the earth, means of production and appropriated surplus-value - is impossible: enacting property right requires the restriction of property right. Hence we have a modified reappearance of the impossibility of the actualisation of these claimed property entitlements within the economy $(6 \S 4)$, now at the level of the state. Whilst these claimants may will the state to grant their claims in the form of legal rights, the latter's activities are nevertheless experienced as an externally imposed power, conflicting with their claims. For these claimants, stamped as right holders, this is revealed in a continuously reappearing conflict of 'willing' and 'not willing' the state. (Enlightened property owners may see that full property right is indeed an impossibility.)

\section{$7 \S 20 \quad$ Conflicts of the form of taxation}

Given that taxation inevitably impairs on property rights $(7 \S 19)$, any concretisation of taxation - that is, regarding various tax bases and the design of tax rates - is further conflicting in that it unavoidably requires the state to take a stance concerning the distribution of income and wealth. This applies to sales taxes and value-added taxes as well as taxes on income and wealth (amplified upon in Chapter 8). For example, there is no obvious reason why a flat tax on income, wealth or succession (on either one or all) should be more impartial 
than regressive or progressive taxes, or whether the one or the other should be more beneficial to the functioning of the economy. ${ }^{25}$

In taking such a stance about the distribution of income and wealth, the state must inevitably introduce considerations and criteria other than those of 'the' market. Thus, considering the capitalist system - not merely the capitalist economy - the criterion of the monetary-value-form, in particular the profit form, is insufficient. This is so even if ideologues may rightly or wrongly argue that the one form of taxation is less market disturbing than the other.

The state's unavoidable stance on the distribution of income and wealth is yet another source of conflict (next to those presented in the previous two sections) that threatens the legitimation of the state.

\section{$7 \S 21 \quad$ The worrying or reassuring state's share in the economy}

The capitalist state's concern of its action radius requires it to further the conditions for the accumulation of capital. Therewith it increases the tax base, whence the tax rate can decrease $(7 \S 3)$.

However, along with it, state expenditure and the amount of taxation increases $\left.{ }_{7} \mathrm{D}_{2-7} \mathrm{D}_{4}\right) \cdot{ }^{26}$ Indirectly, and in part directly, this is also the case for social security transfers $\left({ }_{7} \mathrm{D}_{5}\right)$. Thus directly or indirectly the state commands a larger share of the economy, in comparison with the hypothetical case in which the state would or could abstain from these expenditures and taxation. (Hypothetically, because the capitalist economy and state cannot exist without the seven regulative frameworks. None of these can be dispensed with. For the last five presented in the current chapter - it is merely their quantitative size, or intensity, that is at issue.) Even so, the necessary impact of the state is conflicting among economic actors, in that some perceive it as worrying, whereas for others it is reassuring.

This is even more so for cases when the state's furthering of the conditions for the accumulation of capital, would (along with an increasing tax base) still require increasing tax rates. Then, taking the case of profit taxes, the result might still be that profits increase $(7 \S 21-a$ provides a simple example). The problem for the state is that enterprises tend to isolate the tax (rate) increase as the doing of the state, whilst perceiving the profit increase as their own doing.

25 The ongoing controversy about this - from early classical political economy onwards reveals that there are no obvious reasons for one or the other taxation.

26 Structurally this is in fact not the case for the monetary policy (including surveillance) delegated to the Central Bank, as the latter tends to make profits that are usually distributed to the state. 
$7 \S 21-\mathrm{a} \quad$ Explication. An example of the case of increasing profits along with an increasing tax rate

If $\alpha_{100}$ profits (the tax base) are taxed at $20 \%$, the tax is $\propto_{20}$, with net profits $a 80$. If because of a near to costless furthering of the accumulation-conditions, profits increase to $\alpha_{105}$, the same tax of $\alpha_{2}$ may be collected at a tax rate of $19 \%$. This is the pure case of such a tax alleviation. Now suppose that for a furthering of the conditions an extra tax of $a_{3}$ is required (e.g. for infrastructure). Then, if again profits increase to $a_{105}$, a tax rate of $22 \%$ would generate $x_{23}$ taxes (instead of $a_{20} \%$ before), with net profits $x_{82}$ (instead of $x_{80}$ o before). Hence, in comparison with the initial situation ( $\varpi_{100}$ profits), net profits have increased even if the tax rate increased. With some adaptation of the example it can be shown that profits may increase along with an increasing share of taxes in GDP.

\section{$7 \$ 22 \quad$ General conflicts of legal right and of legitimation in compliance}

The capitalist economy cannot exist without the core economic entitlement claims being granted by the state in the form of legal rights $(6 \S 2-$ $6 \S 4,6 \S 8)$. The legitimation of the state is grounded in the compliance of actors to submit to the state for granting these legal rights (6\$5), as again, ultimately, grounded in the state's definition of the general interest (6§6). It is further grounded in the state's upholding of the granted rights by public security $(6 \S 18)$ and by the arbitration and sanctioning of deviation from the law, as assigned to the judiciary $(7 \S 18)$.

In terms of the state's (non-)regulation as serving the interests of actors, a large part of this regulation, or their level, is experienced in opposite ways by objective classes of actors. Nevertheless the state must somehow seek actor's compliance for what it does, and at the prevailing level so.

- First, workers must comply with:(1) the enterprises' legal right of their being employed (at the prevailing wage, benchmarked by the prevailing legal minimum wage $(7 \S 10)$, and at the prevailing degree of labour protection $(6 \S 15)$ ) whilst the surplus-value that they produce is appropriated by the enterprise; (2) the prevailing content of their (other) rights to existence and of their property (6§14-6§15; $6 \S 10)$; (3) the prevailing public education $(7 \S 14) ;(4)$ the prevailing level of social security provisions $(7 \S 17)$.

- Second, owners of enterprises (including owners of financial titles) must comply with: (1) the state's enacting of their employment rights (1 above); (2) the prevailing maintenance of their rights to existence and property; (3) more specifically concerning the latter, the restriction of their property rights via taxation $(7 \S 2)$ in face of the state's furthering of the conditions of the accumulation of capital $\left({ }_{7} \mathrm{D}_{2}-7 \mathrm{D}_{4}\right)$. 
The effective benefits from regulation for objective classes of actors tend to be opposite or unevenly distributed in terms of subordination and of the distribution of income and wealth. Therefore the constellation of these legal rights and provisions tends to be gravely conflicting, whence the state's ability to present that constellation as being in (its definition of) the general interest is not obvious.

\section{$7 \S 23$ Conflict modification - legitimising assignment to a separated off Deliberative, as a separation-in-unity with the main body of the state}

The conflicts set out in this division $(7 \S 19-7 \S 22)$ threaten the state's legitimation in the compliance of actors. Nevertheless the state's legitimation is a sine qua non for the very existence and reproduction of the capitalist system.

Then the point is not so much whether the state's definition of the general interest 'is' but rather whether it is perceived by the actors as in keeping with the variety of interests, or as proportional to the diversity of interests. In this perspective the opposing interests, and conflicts thereof, require a form of presenting the state's particular legislative choices as a perceived settlement of conflict in the general interest - thus conditioned, the choices are presented as being in the general interest.

This settlement of conflict is grounded in an institutional separation within the state between, on the one hand, the core Administrative Branch and, on the other hand, the legitimising Deliberative. This is an assigned separation within the total body of the state, whence it is a separation-in-unity (analogous to the separation-in-unity of the Administrative and the Judiciary - ${ }_{7} \mathrm{D} 6$ ).

- The Deliberative indeed deliberates over legislative choices and over the state's (non-)actions generally, and so seeks or establishes the compliance of the people for these.

Its particular form is contingent. For example an appointed assembly, a representative assembly of property owners, an assembly of delegates of corporations, a delegated voting of a parliament, a (delegated) voting of a parliament by constituency, or a constitutional democratic representative parliament might all gain the required compliance.

However, given one of these forms, the question of what is being assigned to the deliberative is an open one. (It is not only an open one, in practise many actors do not know what has been assigned - 'them' it is all the same dance.)

The character of the assignment is contingent. The Deliberative might merely 'have a say' and so advice the Administrative. Alternatively it might (in all fields, or merely in particular ones) have final vote, or, together with the Administrative, have a final co-vote on legislative choices. 
However, ultimately there must be a particular form and a particular assignment that does adequately gain the compliance.

- The Administrative body manages - at least - the execution of the law. It is contingent whether it has the final vote or a final co-vote on legislative choices.

In line with the assignment above, it is contingent if the final legislative vote is allotted to either the Administrative, or to the Deliberative, or to a combination of these two.

It is also contingent if the draw up of proposed legislation is allotted to either the Administrative or to a combination of the latter and the Deliberative.

- Hence the legislative organ may contingently consist of the Administrative, or the Deliberative, or of a combination of the two.

Within these contingencies the necessity is that some form of the Deliberative generates the legitimation of the state in the compliance of the vast majority of the people. A condition for it is that at least the influential actors must sufficiently feel to be represented by the legitimising apparatus. It is also necessary that it shields the Administrative core of the state, as much as possible, from conflicts arising from legislation, from (non-)action in general and from taxation in particular.

Hence through this separation-in-unity, the core of the state is purified from conflict, so that it can execute, in the name of the general interest, the granted core economic entitlement claims in the form of law; and execute the furthering of the conditions for economic growth and so for the accumulation of capital. Thus the Deliberative is the political arena of conflict and so a mode for recurrent conflict settlement. Hence it is a mode of existence of conflict.

7§23-a Amplification. Common suffrage: average of OECD-21

All the current $O E C D-21$ countries practice forms of representative democracythe character of the assignment differs. A common and equal suffrage for all ethnicities (also called universal suffrage) regarding the election of parliaments was, on average for these countries, introduced in 1940. Discriminating for ethnicities, a suffrage for men was on average introduced in 1894, and in 1930 also for women. ${ }^{27}$ (Before that time there were restrictions regarding, mainly,

27 The averages are calculated from an anonymous source, and I do not know how reliable it is. https://en.wikipedia.org/wiki/Universal_suffrage\#Dates_by_country (accessed October 2017). 
a minimum income or property.) Regarding the removal of ethnical suffrage discrimination there is quite some variation between individual countries, ranging from Norway (1821) and Ireland (1829) to the USA (1965) and Spain $(1977)^{28}$

$7 \S 23$-b Amplification. Purification from conflict versus 'separation of
powers'

Again, as for the Judiciary ( $7 \S 18-\mathrm{b})$, the exposition in $7 \S 23$ is one from the point of view of the state and its concern to gain legitimating compliance. Thus it is not one from the perspective of non-state actors, such as in 'separation of powers' approaches, or the, democratically more fundamental, approaches for which political democracy is an aspiration in itself. Again, these two are moral ideals (and once again I remark that I would not want to underrate such ideals). And again (Judiciary and Deliberative) a degree of separation of powers is an effect of the purification from conflict.

Given that the exposition in $7 \S 23$ is one from the perspective of the state, the exposition may further be characterised as a variant of 'democratic instrumentalism' (see Peter 2016, section 4) to the extent that democratic deliberation and decisions are a means for legitimation. However, I add the caveat that I draw not a single normative position from it (as is the case with quite some democratic instrumentalists - see Peter's outline).

\section{$7 \S 23-c \quad$ Explication. Purification from conflict by way of assignment or} delegation

In the course of Chapters 6 and 7 we saw a series of 'purifications' - either in the form of assigned separations-in-unity, or in the form of delegated separations (see $7 \S 18$-a on the difference between the two). These have in common that conflicts are encapsulated. Nevertheless that does not away with the conflicts. These separations are summarised in Scheme 7.13.

28 For the 25 other countries listed, common and equal suffrage for all ethnicities was on average introduced in 1950. 
SCHEM 7.13 Summary of the state's purifications from conflict for its administrative core - assigned division and delegation (Chapters 6-7)

\section{Capitalist State in General}

||

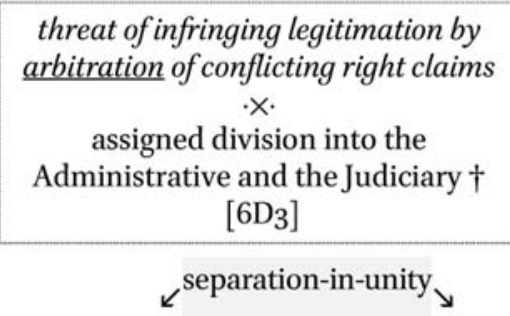

threat of infringing legitimation by
legislating conflicting interests $\cdot x$.

assigned division into the Administrative and the Deliberative $\dagger$ [7D6]

$\swarrow^{\text {separation-in-unity }_{\searrow}}$

\begin{tabular}{|c|c|c|c|c|}
\hline \multirow[t]{5}{*}{$\begin{array}{l}\text { legitimising } \\
\text { Judiciary } \\
{\left[{ }_{7} \mathrm{D} 6\right]}\end{array}$} & \multirow[t]{3}{*}{$\begin{array}{l}\text { purification } \\
\text { from } \\
\text { conflict }\end{array}$} & \multirow{2}{*}{$\begin{array}{l}\text { Administrative [core] } \\
\text { - legislative and } \\
\text { executive, or } \\
\text { - co-legislative and } \\
\text { executive, } \\
\text { - or executive }\end{array}$} & \multirow[t]{3}{*}{$\begin{array}{l}\text { purification } \\
\text { from } \\
\text { conflict }\end{array}$} & \multirow[t]{3}{*}{$\begin{array}{l}\text { legitimising } \\
\text { Deliberative } \ddagger \\
{\left[{ }_{7} \mathrm{D}_{7}\right]}\end{array}$} \\
\hline & & & & \\
\hline & & 11 & & \\
\hline & \multicolumn{3}{|c|}{$\begin{array}{l}\text { threat of infringing legitimation by the execution } \\
\text { of legislation regarding conflicting interests } \\
\qquad\left[7 \mathrm{D}_{2} ; 6 \mathrm{D}_{5}\right]\end{array}$} & \\
\hline & \multicolumn{2}{|c|}{$\begin{array}{l}\text { delegation of } \\
\text { monetary regulation, } \\
\text { supervision and } \\
\text { monetary policy }{ }^{*}\end{array}$} & $\begin{array}{l}\text { of regula- } \\
\text { supervision } \\
\text { duction and } \\
\text { mum wage * }\end{array}$ & \\
\hline $\begin{array}{c}\text { Central Bank } \\
\left.\left[7{ }_{7}\right]^{\prime}\right]\end{array}$ & $\begin{array}{l}\text { purification } \\
\text { from } \\
\text { conflict }\end{array}$ & & $\begin{array}{l}\text { purification } \\
\text { from } \\
\text { conflict }\end{array}$ & $\begin{array}{c}\text { Inspectorates } \\
\text { and Councils } \\
{[6 \S 16 ; 7 \S 11]}\end{array}$ \\
\hline
\end{tabular}

$\dagger$ The extent of the assigned division (the degree of authority) being demarcated by law.

‡ It may have (co-)legislative powers (then the powers of the Administrative vary with it).

* The degree of delegation being demarcated by law.

\section{Legend}

$\cdot \times \cdot \quad$ continuity impediment

\| implicit herein 


\section{Summary and conclusions}

The capitalist state grants core economic entitlement claims in the form of law, and maintains these (Chapter 6). The state's existence requires taxation, whence it is compelled to override property right in the name of its definition of the (putative) general interest. Because the (potential) action radius of the state is determined by the tax base, it must seek to increase that base - so as to reach feasible tax rates - by furthering the conditions for the accumulation of capital and along with it the conditions for economic growth. (Division 1.)

Divisions 2-4 outlined the concretisation of this condition of existence of the state. In terms of the general systematic of the exposition, the first two of these divisions (the monetary framework and the labour-capacity framework) are also the sequel to Chapter 2's grounding of the accumulation of capital in the expansion of money and the expansion of labour-capacity.

The state's taxation and expenditure requires that it impose the monetary standard of 'its' Clearing Bank, whence all banks are required to adopt the monetary standard of the state's Clearing Bank, now the Central Bank (CB). This imposition implies that the state takes a responsibility for the actions of the $\mathrm{CB}$, as concretised in the state's monetary legislation. Limiting banking to licensees, the major concern of this framework is to bind banks to sound security and liability rules ('prudential regulation'), the ultimate penalty for deviation from those rules being the withdrawal of the licence. A second major concern is achieving 'price stability' (in fact 'creeping inflation' - amplified in 9D2). The state can try to influence the interest rate, but it has virtually no means to control the quantity of money and credit. It is the commercial banks that predominantly undertake the money creation, and hence accommodate the accumulation of capital and economic growth. This poses the main dilemma of the state's monetary policy: tight prudential regulation affects the banks' accommodation of economic growth. This is also the main dilemma regarding the fairly recent phenomenon of the monetary system trembling banks that are 'too big to fail' and moreover organisationally too complex to supervise microwise (amplified in 9D2).

Monetary legislation and its execution require choices that affect not only economic growth in general, but more specifically also the distribution of income, investment and unemployment. This implies that the state has to take sides in the (potential) conflicts between labour, enterprises and financiers. As this may erode the ground of the state's legitimation, it tends to delegate the regulative concretisation and execution of monetary policy - including the regulation and supervision of banks - to the Central Bank. By this delegation the state purifies itself from conflict. Nevertheless, as with all delegation, the state is 
ultimately responsible for the actions that it delegates. The latter is highlighted in times of those banking crises that are so severe that their resolution is beyond the means of the $\mathrm{CB}$, whence the state has to step in as 'tax levier of last resort' - eroding the legitimation of the state. (Division 2.)

The state's furthering of the conditions for the accumulation of capital requires it to promote a sufficient labour-capacity in terms of both quantity and quality. The quantitative aspect is concretised in regulation of minimum wages, of temporary unemployment benefits and of (number scaled) temporary child benefits. The qualitative aspect is concretised in state-funded public education. ${ }^{29}$ In face of the conflicting character of especially minimum wages, the state tends to delegate its execution to minimum wage commissions or councils. This is again an effort to purify the core administrative body of the state from conflict. (Division 3.)

An important component of the state's furthering of the conditions for the accumulation of capital is also its engagement in infrastructural networks, as well as, depending on the specific market constellation, in the infrastructural supply itself. A final component is fundamental technology research. (Division 4.)

For its actions and non-actions the state inevitably has to seek and gain legitimation in the compliance of the vast majority of actors. Given that the subordinated working class constitutes the vast majority, it must especially also seek their compliance. This is concretised in various social security provisions, their level being dependent on contingent degrees of (potential) conflict. ${ }^{30}$ Because the legitimation of the state is a sine qua non for the existence of the capitalist system, these transfers are an indirect condition for the accumulation of capital. (Division 5.)

This completes the exposition of the seven main legislative frameworks: those of legal economic rights $\left(6 \mathrm{D}_{4}\right)$, legal existence rights $\left(6 \mathrm{D}_{5}\right)$, public security (6D6), money and banking $\left(7 \mathrm{D}_{2}\right)$, labour-capacity $\left({ }_{7} \mathrm{D}_{3}\right)$, infrastructure $\left.{ }_{7} \mathrm{D}_{4}\right)$, and social security $\left({ }_{7} \mathrm{D}_{5}\right)$.

The so far outlined action of the state that is necessary for the reproduction of the capitalist system is experienced by large groups of actors as conflicting with their interests. Firstly, the state's requirement of taxation implies that legal full property right - in the earth, means of production and appropriated

29 For the case of the average of the OECD-21, state expenditure on public education grew from under $1 \%$ of GDP in 1870 to nearly $6 \%$ around 2015 (Graph 7.6).

30 For the case of the average of the OECD-21, state expenditure on social security provisions was negligible until 1920 and grew thereafter to about $25 \%$ of GDP around 2015 (Graph 7.10). 
surplus-value - is impossible: enacting property right requires the restriction of property right. Secondly, given this restriction, any concretisation of taxation (regarding various tax bases and design of tax rates) is further conflicting in that it unavoidably requires the state to take a stance concerning the distribution of income and wealth. This is generally and continuously the case. It is highlighted in times of severe banking crises, when the state as 'tax levier of last resort' saves banks, and so redistributes general means to one particular sector. Thirdly, the state's necessary action - including its furthering of the conditions for the accumulation of capital, and its provision of social security provisions - implies that the state commands a considerable share of the economy. This impact of the state is conflicting among economic actors, in that some perceive it as disquieting, whereas for others it is reassuring. Fourthly, and generally, in terms of the state's actions serving the interests of actors, a large part of these actions are experienced in opposite ways by the objective classes of actors.

All these conflicts threaten the state's legitimation. Nevertheless the legitimation of the state is an absolute requirement for the very existence and reproduction of the capitalist system.

The settlement of these conflicts is grounded in two major institutional 'assigning separations' within the state, between, on the one hand, the core Administrative body and, on the other, the bodies of a legitimising Judiciary and a legitimising Deliberative.

With the necessary arbitration and sanctioning of deviations from the law (6§9), the state gets involved with conflicting claims to right, so eroding both its reference to the general interest and its self-imposition as an extraordinary impartial institution. This is resolved by assigning the arbitration and sanctioning to a separated off judiciary, whence the state's core is purified from the conflicts concerned. (Division 6.)

The Deliberative is the necessary political arena of conflict and so a mode for recurrent conflict settlement. Through this separation, the core of the state is equally purified from conflict, so that it can execute the granting of the core economic entitlement claims in the form of law, and execute the frameworks of furthering the conditions for economic growth and thus for the accumulation of capital. (Division 7.)

\section{Appendix 7A. data and data sources of the graphs in chapter 7}

General note: For all years (1870 to current) I have used the maximum amount of information that my sources provide for the OECD-21 countries. Qualifica- 
tions of this are provided throughout this Appendix. (See Appendix 6A on the 'OECD-21', on OECD-21 averages as 'arithmetic average' and on my main sources.)

[Re 7§3-b] Data information on Graph 7.3. Real-GDP per capita 1850-2010, growth rate per year (top graph) and average per decade (bottom graph); average of 20-21 current OECD countries in 2011 US\$.

The data originate from those collected by Maddison, and which, after his death, continued in the so-called Maddison Project. The data used are those from the 2018 revision. ${ }^{31}$ Of its two main datasets I used the real-GDP per capita CGDPpc one. (In fact for the average of the OECD-21 countries the differences with the alternative dataset of RGDPNApc are not very big.) Continuous data for Ireland are available only from 1921.

[Re 7\$14-c] Data information on Graph 7.5. Years of formal schooling and distribution of schooling 1870-2010, average of 21 current OECD countries.

The data are from Clio Infra. https://www.clio-infra.eu/ (accessed 27 February 2016). The graph of the number of years is of 21 countries throughout. That for the distribution is of 13 countries for $1870-80,17$ for 189 o, 18 for 1900,20 for $1910-20$ and 21 for 1930 and after. The Clio Infra website also provides information about the method of calculation of the Gini-coefficients.

[Re 7\$14-d] Data information on Graph 7.6. Education expenditure, general government 1870-2014, average of up to 21 current OECD countries.

Data sources 1870-1960 (Tanzi and Schuknecht 200o); 1970-current (UNESCO institute for statistics, dataset education)

Tanzi and Schuknecht (2000, Table II.5) provide data of 5 current OECD countries in 1870, 8 in 1913, 11 in 1937 and 17 in 196o.

The UNESCO data are from their May 2017 release. ${ }^{32}$ There are some gaps in even these recent UNESCO data (from 1970), which I have accommodated by taking for each country the decade year or the nearest year available (in the same way as the OECD often does for its series). This results in the following number of country data for each decade year and for 2014:

31 https://www.rug.nl/ggdc/historicaldevelopment/maddison/releases/maddison-projectdatabase-2018, update 11 January 2018. See also Bolt, Inklaar, de Jong and Luiten van Zanden 2018.

32 UNESCO, dataset education (financial resources/government expenditure on education), http://data.uis.unesco.org/OECDStat_Metadata/ShowMetadata.ashx?Dataset=EDULIT_ DS\&ShowOnWeb=true\&Lang=en (accessed 27 December 2017). 


\begin{tabular}{lccccc}
\hline 1970 & 198 o & 1990 & 2000 & 2010 & 2014 \\
\hline 15 & 19 & 21 & 21 & 20 & 20 \\
\hline
\end{tabular}

[Re 7\$15-a] Data information on Graph 7.7. State expenditure (general government) on gross investment, 1870-2015, average of up to 21 current OECD countries. For the OECD countries, internationally more or less homogenous data for state expenditure on infrastructure are only available from 1995. Therefore, as indicated in $7 \S 15$, I use a major fraction $(57.5 \%)$ of the state gross investment expenditure (general government) as an indicator for this category. Below I provide an underpinning of this proxy. All figures below are averages of up to 21 OECD countries. ${ }^{33}$

Transport is the main component of infrastructural state expenditure. Between 1995 and 2013 this expenditure stood fairly stable at an average of $1.36 \%$ of GDP. ${ }^{34}$ (Part of COFOG category 4.5.) Expenditure on communication (COFOG 4.6) was between 1995 and 2013 negligible (though there may be state ownership in communication corporations). Other infrastructural expenditures are classified under the COFOG category 5 . These are mainly expenditures on waste and waste water facilities. The $1995^{-2013}$ average expenditure is $0.67 \%$ of GDP. The sum of these is $2.0 \%$ of GDP.

State gross investment (general government) stood between 1995 and 2013 at an average of $3.5 \%$ of GDP (OECD-21). The 0.575 fraction of this is $2.0 \%$ of GDP. ${ }^{35}$

In Chapter 10, when I use data for recent decades, the remaining $42.5 \%$ of the gross investment is allotted to the other expenditure categories, including

33 In what follows I make use of the OECD 'COFOG' data (Classification of the Functions of Government). In this classification government expenditures are categorised in ten 'functions' ('first digit'), and further down - below called 'digit level'.

34 This figure is decomposed as 'investment in transport infrastructure' at $0.9 \%$ (data for 21 countries) and maintenance at $0.5^{\%}$ (data for 15-18 countries). Averages of the 'OECD-21' as calculated on basis of data from the OECD International transport forum http://stats .oecd.org/OECDStat_Metadata/ShowMetadata.ashx?Dataset=ITF_INV-MTN_DATA\& ShowOnWeb=true\&Lang=en $(\rightarrow$ December 2015). (These expenditures are part of COFOG category 4.5. The source just quoted has more data. Moreover, the COFOG 4 digit 2 level is organised by sector rather than specifically infrastructural.)

35 Note that the infrastructure indicator regards indeed an average for the OECD-21. In the USA, for example, an above average part of the federal government gross investment has a military destination. 
mainly the military, health and education (as well as what in that chapter will be called 'hard core' expenditure).

Graph 7.7- $a$ shows the deviation of the investment indicator from the 19952013 expenditures on infrastructure.

GRAPH 7.7-A Infrastructural state expenditure and the infrastructure indicator of state gross investment, 1995-2013, averages of up to 21 OECD countries

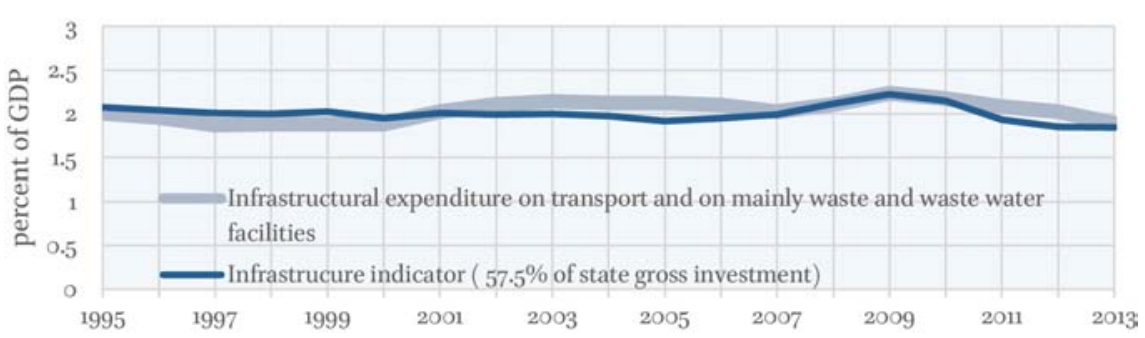

DATA SOURCES: Infrastructural expenditure on transport, OECD International transport forum (see the last but one footnote); waste and waste water facilities, OECD dataset National Accounts at a Glance 2015, General government expenditure by function, environment protection (COFOG 5 ); ${ }^{36}$ state gross investment, see Graph 7.7 (main text)

[Re $7 \S 15$-a] Further data information on Graph 7.7. Gross investment expenditure, general government 1870-2015, average of up to 21 current OECD countries.

Data sources. 1870-1937 (Tanzi and Schuknecht 20oo, Table II.13); 1960current (OECD Economic Outlook database, November 2017 (Government fixed capital formation, value, appropriation account, divided by GDP, value, market prices)). [Denmark and New Zealand 1970=1971; Germany 1990=1991.]

For reasons of consistency with later years I have started using the Economic Outlook (new) series from as early as possible, which is 196o. For this last year, however, only 6 data are available (Finland, France, Italy, Japan, Sweden, USA), with an average of 5.3\% GDP. However, as Graph 7.7 shows there is a considerable fit between 6 country and 13 country averages in 1970; that graph also shows that there is not very much deviation between the averages for 13 countries (from 1970) and for 21 countries (from 2000).

36 http://stats.oecd.org/index.aspx?DatasetCode=NAAG_2015_NOV15 (extracted 24 Dec 2015). 
[Re 7 \$17-a] Graph 7.9. State expenditure (general government) on specific categories of social security transfers 1980-2010, in \% of GDP; averages of $19-21$ OECD countries.

Data sources. Area charts (OECD, database 'Social Expenditure; Aggregated data [socx]'). ${ }^{37}$ Unemployment rate (dataset oEcD, Economic Outlook, November 2017). ${ }^{38}$

For most categories these social expenditure data are available of 19-21 countries -2013 being the last reported year. The unemployment data are available of $18-21$ countries (Germany 1990=1992).

[Re 7 §17-a]

TABLE 7.9-A Specification of social security expenditure 1980-2010 in \% of GDP; averages of 19-21 OECD countries

\begin{tabular}{|c|c|c|c|c|c|c|c|c|}
\hline \multirow[b]{2}{*}{ expenditure categories } & \multicolumn{4}{|c|}{$\begin{array}{l}\text { Percent of GDP } \\
\text { (except last row) }\end{array}$} & \multicolumn{4}{|c|}{ Percent linear change } \\
\hline & 198 o & $199 \circ$ & 2000 & 2010 & $1980-90$ & $1990-00$ & $2000-10$ & $\begin{array}{l}1980- \\
2010\end{array}$ \\
\hline old age and survivors & 6.5 & $7 \cdot 4$ & $7 \cdot 9$ & 9.2 & $13 \%$ & $7 \%$ & $17 \%$ & $40 \%$ \\
\hline health & $4 \cdot 7$ & 4.9 & $5 \cdot 4$ & 6.9 & $4 \%$ & $11 \%$ & $27 \%$ & $47 \%$ \\
\hline family & 1.6 & 1.7 & 2.0 & 2.4 & $5 \%$ & $14 \%$ & $19 \%$ & $43 \%$ \\
\hline housing & 0.3 & 0.3 & 0.4 & 0.4 & $31 \%$ & $10 \%$ & $14 \%$ & $64 \%$ \\
\hline incapacity & 2.4 & 2.5 & 2.4 & 2.4 & $7 \%$ & $-6 \%$ & $3 \%$ & $3 \%$ \\
\hline unemployment & 0.7 & 1.2 & 0.9 & 1.3 & $58 \%$ & $-18 \%$ & $33 \%$ & $74 \%$ \\
\hline all social security & 16.6 & 19.0 & 20.1 & 23.8 & $14 \%$ & $6 \%$ & $18 \%$ & $44 \%$ \\
\hline total state expenditure & 42.4 & $45 \cdot 4$ & 42.4 & 48.6 & $7 \%$ & $-6 \%$ & $15 \%$ & $15 \%$ \\
\hline rate of unemployment & 4.9 & 6.4 & 6.3 & 8.3 & $30 \%$ & $-7 \%$ & $32 \%$ & $69 \%$ \\
\hline
\end{tabular}

DATA SOURCE: see Graph 7.9

37 http://stats.oecd.org/index.aspx?DatasetCode=SOCXAGG (extracted 27 Dec 2017).

38 http://stats.oecd.org/index.aspx?DatasetCode=EO1O2_INTERNET (extracted 27 Dec 2017). 
It can be seen from Table 7.9- $a$ that from 1980-2010 the sum of social security expenditure increased considerably more than total state expenditure. However, incapacity transfers and especially unemployment transfers lagged behind from 1990-2010, and more so than the movement in the rate of unemployment.

\section{List of figures chapter 7}

Scheme 7.1 The conditions furthering the accumulation of capital (outline Chapter 7) 334

$7 \S 3$. The tax base, the potential action radius of the state, and the state's furthering of the conditions for the accumulation of capital

Scheme 7.2 The grounding of the state's action radius in its furthering of the conditions for the accumulation of capital (systematic of $7 D_{1}$ ) 337

Graph 7.3 Real-GDP per capita 1870-2010, growth rate per year (top graph) and average per decade (bottom graph); average of 20-21 current OECD countries in 2011 US\$ 339

$7 \S 7$. Delegation of the specific regulation, of the supervision of its execution and of monetary policy to the central bank: purification from conflict

Scheme 7.4 From taxation to conflicts of monetary regulation and conflict delegation (systematic of $7 \mathrm{D}_{2}$ ) 343

7\$14. Public education

Graph 7.5 Years of formal schooling and distribution of schooling 1870-2010; average of 21 current $O E C D$ countries 353

Graph 7.6 State expenditure (general government) on education, 1870 to 2014, in $\%$ of GDP; average of up to 21 current OECD countries 354

$7 \S 15$. Infrastructure

Graph 7.7 State expenditure (general government) on gross investment, 1870-2015, average of up to 21 current OECD countries 357

7 \$17. Legitimation: compliance-dependent social security transfers

Figure 7.8 Legal forms of regulation of production and of existence security 361

Graph 7.9 State expenditure (general government) on specific categories of social security transfers 1980-2010, in \% of GDP; averages of $19-21$ OECD countries 362 
Graph 7.10 State expenditure (general government) on social security $1880-2015$, average of up to 21 current OECD countries 363

Graph 7.11 Social security expenditure and total state expenditure (general government) 1870-2015 in \% of GDP; averages of up to 21 current OECD countries $\quad 364$

$7 \S 18$. Arbitration and sanctioning - legitimising assignment to a separated off Judiciary, as a separation-in-unity with the main body of the state

Scheme 7.12 Arbitration and sanctioning as assigned to the separate Judiciary: separation-in-unity with the state's main body 366

$7 \S 23$. Conflict modification - legitimising assignment to a separated off Deliberative, as a separation-in-unity with the main body of the state

Scheme 7.13 Summary of the state's purifications from conflict for its administrative core-assigned division and delegation 374

Appendix 7 A. Data and data sources of the graphs in chapter 7

Re 7 §3-b; $\quad$ Graph $7.3 \quad 378$

Re 7 §14-c; $\quad$ Graph $7.5 \quad 378$

Re 7 §14-d; $\quad$ Graph $7.6 \quad 378$

Re $7 \S 15$-a; $\quad$ Graph $7.7 \quad 379$

Re $7 \S 15^{-a}$; $\quad$ Graph 7.7-a. Infrastructural state expenditure and the infrastructure indicator of state gross investment, 1995-2013 380

Re $7 \S 15$-a; $\quad$ Graph 7.7 (continued) 380

Re $7 \S 17-\mathrm{a} ; \quad$ Graph $7.9 \quad 381$

Re 7§17-a; $\quad$ Table 7.9-a. Specification of social security expenditure 1980-2010 in \% of GDP; averages of 19-21 OECD countries 381 